\title{
Annual Report of Tank Waste Treatability
}

Prepared for the U.S. Department of Energy Office of Environmental Restoration and Waste Management

\section{(2) Westinghouse \\ Hanford Company Richland, Washington}

Hanford Operations and Engineering Contractor for the

U.S. Department of Energy under Contract DE-AC06-87RL10930 


\section{LEGAL DISCLAIMER}

This report was prepared as an account of work sponsored by an agency of the United States Government. Neither the United States Government nor any agency thereof, nor any of their employees, nor any of their contractors, subcontractors or their employees, makes any warranty, express or implied, or assumes any legal liability or responsibility for the accuracy, completeness, or any third party's use or the results of such use of any information, apparatus, product, or process disclosed, or represents that its use would not infringe privately owned rights. Reference herein to any specific commercial product, process, or service by trade name, trademark, manufacturer, or otherwise, does not necessarily constitute or imply its endorsement, recommendation, or favoring by the United States Government or any agency thereof or its contractors or subcontractors. The views and opinions of authors expressed herein do not necessarily state or reflect those of the United States Government or any agency thereot.

This report has been reproduced from the best available copy Available in paper copy and microfiche.

Available to the U.S. Department of Energy and its contractors from

Olfice of Scientific and Technical Information P.O. Box 62

Oak Ridge, TN 37831

(615) $576 \cdot 8401$

Available to the public from the U.S. Department of Commerce National Technical Information Service

5285 Port Royal Road

Springfield, VA 22161

(703) $487-4650$

Printed in the Uniled States of America 


\title{
Annual Report of Tank Waste Treatability
}

\author{
K. A. Giese
}

Date Published

September 1991

Prepared for the U.S. Department of Energy Office of Environmental Restoration and Waste Management 
WHC-EP-0365-1

ANNUAL REPORT OF TANK WASTE TREATABILITY

September 1991

Prepared By: $\frac{\mathscr{f} \text {. A. Mise } 9-27-9 /}{\begin{array}{l}\text { K.A. Giese, Senior Engineer } \\ \text { Waste Tank Equipment Technology }\end{array}}$ Approved: $\begin{aligned} & \text { W. F. Zuroffy Manager } \\ & \text { Waste Tank Equipment Technology }\end{aligned}$ 
WHC-EP-0365-1

\section{ACKNOWLEDGEMENTS}

The author wishes to thank Jason Adler, Harry Babad, Steve Barker, Jerry Bloom, John Conner, Dale Halgren, Betty Hanion, Joe Koerner, Ed Manthos, Phillip Miller, John Rawlins, Rich Sexton, Lisa Schwartz, Roger Szelmeczka, Mitch Vitulli, and Jay Warwick. In addition, the author thanks Kevin Selby of Pacific Northwest Laboratory. 
WHC-EP-0365-1

This page intentionally left blank. 
WHC-EP-0365-1

ANNUAL REPORT OF TANK WASTE TREATABILITY

K. A. Giese

\section{ABSTRACT}

This report has been prepared as part of the Hanford Federal Facility Agreement and Consent Order* (Tri-Party Agreement) and constitutes completion of Tri-Party Agreement Milestone M-04-00 for fiscal year 1991. This report provides a summary of treatment activities for newly generated waste, existing double-shell tank waste, and existing single-shell tank waste, as well as a summary of grout disposal feasibility, glass disposal feasibility, alternate methods for disposal, and safety issues which may impact the treatment and disposal of existing defense nuclear wastes.

This report is an update of the 1990 report and is intended to provide traceability for the documentation of the areas listed above by statusing the studies, activities, and issues which occurred in these areas over the period of March 1, 1990, through February 28, 1991. Therefore, ongoing studies, activities, and issues which were documented in the previous (1990) report are addressed in this subsequent (1991) report.

*Hanford Federal Facility Agreement and Consent Order, Washington State Department of Ecology, Olympia, Washington; U.S. Environmental Protection Agency, Region 10, Seattle, Washington; and U.S. Department of Energy, Richland, Washington (May 1989). 


\section{WHC-EP-0365-1}

This page intentionally left blank. 
WHC-EP-0365-1

\section{CONTENTS}

1.0 INTRODUCTION . . ................... . . . . .

1.1 TRI-PARTY AGREEMENT . . . . . . . . . . . 1-1

1.2 MILESTONE M-04-00, ANNUAL TANK WASTE TREATABILITY 1990 REPORT . . . . . . . . 1-1

1.3 MILESTONE M-04-00, ANNUAL TANK WASTE TREATABILITY 1991 REPORT . . . . . . . . . 1-1 1.3.1 Al ternative Treatment/Dispos:1 Technology ...... 1-1 1.3.2 Safety Issues ................ . . 1-1

2.0 SUMMARY . . . . . . . . . . . . . . 2-1

2.1 DOUBLE-SHELL TANKS ................. 2-1

2.2 SINGLE-SHELL TANKS ................... $2-1$

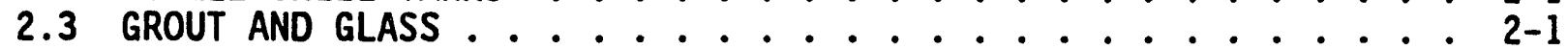

2.4 CURRENT WASTE GENERATORS $\ldots \ldots \ldots$

2.5 UNREVIEWED SAFETY QUESTIONS . . . . . . . 2-2

2.6 ALTERNATIVE TREATMENT/DISPOSAL TECHNOLOGIES . . . . . . 2-2

3.0 TREATMENT OF EXISTING DOUBLE-SHELL TANK WASTES . . . . . . . 3-1

3.1 INTRODUCTION $\ldots \ldots$

3.2 PLANNED TREATMENT OF DOUBLE-SHELL SLURRY FEED AND

DOUBLE-SHELL SLURRY . . . . . . . . . . . 3-1

3.2.1 Definition of Double-Shell Slurry Feed and

Double-Shell slurry ... . . . . . . . . 3-1

3.2.2 Planned Treatment of Double-Sheil siurry Feed and
Double-Shell Slurry . . 3-4

3.3 PLANNED TREATMENT OF NEUTRALIZED CURRENT ACID WASTE $\ldots \ldots . .3-4$

3.3.1 Definition of Neutralized Current Acid Waste . . . . 3-4

3.3.2 Planned Treatment Process of Neutralized Current

Acid Waste . . . . . . . . . . . . 3-4

3.3.3 Schedule . . . . . . . . . 3-6

3.4 PLANNED TREATMENT OF NEUTRALIZED CLADDING REMOVAL WASTE . . . 3-6

3.4.1 Definition of Neutralized Cladding Removal Waste . . 3-6

3.4.2 Planned Treatment Process of Neutralized Cladding

Removal Waste .............. 3-6

3.4.3 Schedule . . . . . . . . . . 3-8

3.5 PLANNED TREATMENT OF PLUTONIUM FINISHING PLANT WASTE $\ldots \ldots 3-8$

3.5.1 Definition of Plutonium Finishing Plant Waste . . . 3-8

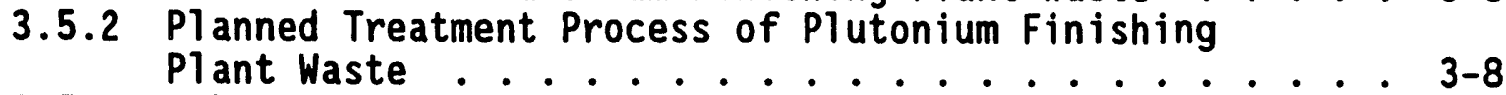

3.5.3 Schedule . . . . . . . . . 3-8

3.6 PLANNED TREATMENT OF COMPLEXANT CONCENTRATE WASTE $\ldots \ldots$

3.6.1 Definition of Complexant Concentrate Waste . . . 3-8

3.6.2 Planned Treatment Process of Complexant Concentrate

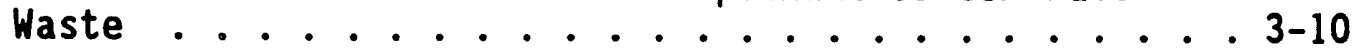

3.6.3 Schedule . . . . . . . . . . . 3-10

3.7 TREATMENT OF WASTE AFTER PRETREATMENT ACTIVITIES ..... 3-10

3.7.1 Grout Treatment . . . . . . . . . . . . 3-10

3.7.2 Hanford Waste Vitrification Plant ....... 3-10

3.8 SUMMARY OF DOUBLE-SHELL TANK WASTE TREATMENT $\ldots \ldots \ldots . . .3-12$ 


\section{CONTENTS (continued)}

4.0 TREATMENT OF EXISTING SINGLE-SHELL WASTES . . . . . . . . 4-1

4.1 DESCRIPTION OF SINGLE-SHELL TANK WASTES ......... 4-1

4.2 TREATMENT OF SINGLE-SHELL TANK WASTES ......... 4 4-1

4.3 STATUS OF SINGLE-SHELL TANK WASTE TREATMENT STUDIES . . . . . 4-7

4.3.1 Destruction of Complexant Concentrate Waste . . . . 4-7

4.3.2 Removal of Transuranic Components by the

TRUEX Process .......... . . . . 4-7

4.3.3 The Strontium Extraction Process . . . . . . . 4 4-7

4.4 LITERATURE AND LABORATORY STUDIES . . . . . . . . . . . 4-8

4.5 TECHNOLOGY PROGRAM PLANS ............... 4-8

4.6 SYSTEMS ENGINEERING STUDY . . . . . . . . . . . . 4-9

5.0 EVALUATION AND SELECTION OF GROUT .............. . . 5-1

5.1 REGULATORY CHANGES AFFECTING GROUT ........... 5-1

5.2 NEW ACTIVITIES . . . . . . . . . . . . 5-2

5.3 STATUS OF ACTIVITIES IN PROGRESS .......... 5-3

5.4 ESTIMATE OF PLANNED WORK ACTIVITIES FOR $1992 \ldots \ldots . . . . .5-3$

6.0 EVALUATION AND SELECTION OF BOROSILICATE GLASS . . . . . . . . 6-1

6.1 INTRODUCTION ....... 6-1

6.2 FISCAL YEAR 1991 WASTE FORM QUALIFICATION ACTIVITIES . . . . 6-1

6.3 FISCAL YEAR 1992 WASTE FORM QUALIFICATION ACTIVITIES . . . . 6-2

7.0 ALTERNATIVE TREATMENT/DISPOSAL TECHNOLOGY . . . . . . . 7-1

8.0 SAFETY ISSUES . . . . . . . . . . . . . . . 8-1

8.1 DESCRIPTION OF TANK WASTE SAFETY ISSUES ......... 8-1

8.2 FLAMMABLE GAS GENERATING TANKS ............. 8-2

8.3 TANKS CONTAINING FERROCYANIDE . . . . . . . . . . . 8-3

8.4 TANKS CONTAINING ORGANIC WASTE ............. 8-4

8.5 HIGH-HEAT TANK . . . . . . . . . . . . . 8-5

8.6 POTENTIAL IMPACT ON TREATMENT . . . . . . . . . .

9.0 REFERENCES . . . . . . . . . . . . . . . . 9-1 APPENDIX

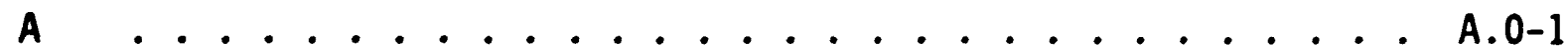


WHC-EP-0365-1

\section{LIST OF FIGURES}

3-1 Neutralized Current Acid Waste Pretreatment and Disposal . . . . . 3-5

3-2 Neutralized Cladding Removal Waste Pretreatment and Disposal . . . . 3-7

3-3 Plutonium Finishing Plant Waste Pretreatment and Disposal . . . . . 3-9

3-4 Complexant Concentrate Waste Pretreatment and Disposal . . . . . . 3-11

\section{LIST OF TABLES}

3-1 Double-She11 Tank Inventory as of February 1991 . . . . . . . . . 3-2

4-1 Single-Shell Tank Inventory as of February 1991 . . . . . . . . . . 4-2

8-1 Safety Issue Tanks ..................... 8-6 
ANL
CAP
CC
CFR
CRW
CURE
DOE
DST
DSS
DSSF
DWPF
ECOI ogy
EPA
ER
FY
GTF
HLW
HWVP
LFL
LLW
NCAW
NCRW
OTD
PFP
PNL
PRF
PUREX
RCRA
SEIS
SREX
SRL
SST
TOC
TRU
TRUEX
UST/ID
WAC
WAPS
Westinghouse Hanford
Argonne National Laboratory

Characterization and Assessment Program complexant concentrate

Code of Federal Regulations

cladding removal waste

clean use of reactor energy

U.S. Department of Energy

double-shell tank

double-shell slurry

double-shell slurry feed

Defense Waste Processing Facility

Washington State Department of Ecology

U.S. Environmental Protection Agency

environmental restoration

fiscal year

Grout Treatment Facility

high-level waste

Hanford Waste Vitrification Plant

lower flammability limit

low-level waste

neutralized current acid waste

neutralized cladding removal waste

Office of Technology Development

Plutonium Finishing Plant

Pacific Northwest Laboratories

Plutonium Reclamation Facility

Plutonium/Uranium Extraction (Plant)

Resource Conservation and Recovery Act

supplemental environmental impact statement

strontium extraction

Savannah River Laboratory

single-shell tank

total organic carbon

transuranic (waste)

transuranium extraction

underground storage tank/integrated demonstration

Washington Administrative Code

Waste Acceptance Prel iminary Specifications

Westinghouse Hanford Company 
WHC-EP-0365-1

ANNUAL REPORT OF TANK WASTE TREATABILITY

\subsection{INTRODUCTION}

\subsection{TRI-PARTY AGREEMFNT}

The tasis for this Annual Report of Tank Waste Treatability is the Hanford Federal Facility Agreement and Consent Order (Tri-Party Agreement) (Ecology 1989) which was established in 1989 by the U.S. Department of Energy (DCE), the U.S. Environmental Protection Agency (EPA), and the Washington State Depar inent of Ecology (Ecology). The Tri-Party Agreement contains milestone M-04-00 which addresses tank waste treatability.

Milestone M-04-00 requires that reports of tank waste treatability studies be submitted annually beginning in September 1990.

\subsection{MILESTONE M-04-00, ANNUAL TANK WASTE TREATABIL LTY 1990 REPORT}

This report was the first Tank Waste Treatability Report of an annual series required by Milestone M-04-00 (WHC 1990). This first report provided an historical perspective of tank waste treatment, described planned treatment of existing double-shell tank (DST) and single-shell tank (SST) wastes, and provided the technical basis for selection of grout and glass as disposal forms.

\subsection{MILESTONE M-04-00, ANNUAL TANK WASTE TREATABILITY 1991 REPORT}

The 1991 report is the first statusing report of these annual reports. The organization of the 1991 report is the same as that of the 1990 version, with two additional sections added as follows.

\subsubsection{Alternative Treatment/Disposal Technology}

Section 7.0 summarizes alternative treatment/disposal technologies which may have an impact on future disposal. These alternative technologies may or may not be mutually exclusive to the current disposal options.

\subsubsection{Safety Issues}

Section 8.0 contains pertinent issues which may affect either the treatability of tank waste or the feasibility of using glass or grout (or another viable alternative) as a final disposal option. 
WHC-EP-0365-1

This page intentionally left blank. 


\subsection{SUMMARY}

This second Annual Report of Tank Waste Treatability document satisfies Tri-Party Agreement Milestone M-04-00 for fiscal year (FY) 1991.

\subsection{DOUBLE-SHELL TANKS}

Existing waste in ten DSTs will be treated to separate the waste into high-level waste (HLW), transuranic (TRU) waste, and low-level waste (LLW) volumes. An evaluation of the suitability of B Plant for the processing of these DST wastes is under way in FY 1991 with accomplishments enumerated in the section on DST waste treatability. Eight as $L L W$ and will not require pretreatment prior to disposal in a grout valit.

Treatment of the separated HLW and TRU waste fractions will consist of vitrification in the Hanford Waste Vitrification Plant (HWVP) before disposal in a geologic repository. Treatment of the LLW consists of solidification in cement-based grout before disposal in near-surface vaults at the Hanford Site. These treatment processes are in various stages of development and are discussed in the section on DST waste treatability.

\subsection{SINGLE-SHELL TANKS}

Existing waste continues to be characterized to enable appropriate treatment options to be developed. This information is needed for a supplemental environmental impact statement (SEIS) leading to a decision on final SST waste disposal.

Studies which address treatment and disposal options were performed in FY 1990. Some of these are ongoing activities which are revised as new information becomes available.

\subsection{GROUT AND GLASS}

Changes in requirements which regulate the disposal of vitrified $H L W$ in a geologic repository are described. Documentation that supports the selection of the grout waste form for disposal of LLW in near-surface concrete vaults at the Hanford Site is described.

\subsection{CURRENT WASTE GENERATORS}

Currently, ten major facilities generate waste. They are the following:

- 100-N Area

- 300 Area

- 400 Area

- Tank Farms

- Evaporators

- Plutonium Finishing Plant (PFP) 
- Plutonium/Uranium Extraction (PUREX) Plant

- B Plant

- S Plant

- T Plant.

Treatment of this waste is addressed in Appendix $A$.

\subsection{UNREVIEWED SAFETY QUESTIONS}

This section contains pertinent issues which may affect either the treatability of tank waste or the feasibility of using glass or grout (or another viable alternative) as a final disposal option.

The four major issues that are summarized in the 1991 report are:

- Hydrogen Issue

- Ferrocyanide Issue

- Organic Issue

- High-Heat Tanks Issue.

\subsection{ALTERNATIVE TREATMENT/DISPOSAL TECHNOLOGIES}

This section summarizes alternative treatment/disposal technologies which may have an impact on future disposal. 
WHC-EP-0365-1

\subsection{TREATMENT OF EXISTING DOUBLE-SHELL TANK WASTES}

This section documents the studies, activities, and issues which occurred in this area over the period of March 1, 1990, through February 28, 1991.

\subsection{INTRODUCTION}

Treatment of existing DST wastes is required before permanent disposal (Augustine 1989). The treatment strategy is to separate DST wastes into three portions: HLW, TRU waste, and LLW. Ten DSTs will be pretreated to separate the waste into HLW, LLW, and TRU volumes. Eighteen DSTs are currently designated as LLW and will not require pretreatment prior to disposal in a grout vault.

Treatment of the separated HLW and TRU waste fractions will consist of vitrification in the HWVP before disposal in a Federal geologic repository. Treatment of the LLW consists of solidification in cement-based grout before disposal in near-surface vaults at the Hanford Site.

These treatment processes are in various stages of development as discussed below. The planned treatment activities will be discussed according to the waste types of double-shell slurry feed (DSSF), doubie-shell slurry (DSS), neutralized current acid waste (NCAW), neutralized cladding removal waste (NCRW), PFP waste, and complexant concentrate (CC) waste.

The current waste volume inventory of the Hanford Site tank farms as of February 1991 is listed in Table 3-1. This information is available from the Tank Farm Surveillance and Waste Status Summary Report for February 1991, WHC-EP-0182-35 (Hanlon 1991). The volumes of both solids and 1iquids are in thousands of gallons.

Tables 3-1 and 3-2 contain references to waste types other than NCAW (designated as Aging), NCRW (designated PN/PD), PFP (designated PT), CC, DSS, and DSSF. The alternate wastes CP, DC, and DN will be concentrated, reclassified, and treated as the appropriate waste type of CC or DSS.

\subsection{PLANNED TREATMENT OF DOUBLE-SHELL SLURRY FEED AND DOUBLE-SHELL SLURRY}

\subsubsection{Definition of Double-Shell Slurry Feed and Double-Shell siurry}

Many streams that enter DSTs consist of dilute liquids low in radioactivity. These streams are so concentrated by Evaporator 242-A that a second pass through the 242-A Evaporator would increase the sodium aluminate concentration past the sodium phase boundary, and the stream would solidify when cooled. At this point the waste is called DSSF. When the DSSF is processed through Evaporator 242-A, the DSSF is concentrated past the sodium aluminate phase boundary. The hot slurry is pumped to a DST where it forms solids as it cools. The waste is then called DSS. 
Table 3-1. Double-Shell Tank Inventory as of February 1991. (2 sheets)

\begin{tabular}{|c|c|c|c|c|c|c|}
\hline \multirow{2}{*}{$\begin{array}{l}\text { Tank } \\
\text { No. }\end{array}$} & \multirow{2}{*}{$\begin{array}{c}\text { Waste } \\
\text { material" }\end{array}$} & \multicolumn{5}{|c|}{ Volume in kgal } \\
\hline & & $\begin{array}{l}\text { Total } \\
\text { waste }\end{array}$ & Supernatant & DSS & Sludge ${ }^{b}$ & Saltcake \\
\hline 101-AN & DN & 353 & 353 & 0 & 0 & 0 \\
\hline 102-AN & CC & 1,099 & 1,010 & 0 & 89 & 0 \\
\hline 103-AN & DSS & 950 & 13 & 937 & 0 & 0 \\
\hline 104-AN & DSSF & 1,066 & 802 & 0 & 264 & 0 \\
\hline 105-AN & DSSF & 1,129 & 1,129 & 0 & 0 & 0 \\
\hline 106-AN & $C P$ & 1,019 & 1,002 & 0 & 17 & 0 \\
\hline $107-A N$ & CC & 1,079 & $94 !$ & 0 & 134 & 0 \\
\hline 101-AP & DN & 1,063 & 1,063 & 0 & 0 & 0 \\
\hline 102-AP & DN & 134 & 134 & 0 & 0 & 0 \\
\hline 103-AP & DN & 956 & 956 & 0 & 0 & 0 \\
\hline 104-AP & DN & 21 & 21 & 0 & 0 & 0 \\
\hline 105-AP & DSSF & 826 & 826 & 0 & 0 & 0 \\
\hline 106-AP & DN & 1,135 & 1,135 & 0 & 0 & 0 \\
\hline 107-AP & DN & 1,130 & 1,130 & 0 & 0 & 0 \\
\hline 108-AP & DN & 136 & 136 & 0 & 0 & 0 \\
\hline 101-AW & DSSF & 1,119 & 1,035 & 0 & 84 & 0 \\
\hline 102-AW & DN & 1,030 & 1,029 & 0 & 1 & 0 \\
\hline 103-AW & DN/PD & 647 & $28 n$ & 0 & 363 & 0 \\
\hline 104-AW & DN & 1,078 & 788 & 0 & 179 & 111 \\
\hline 105-AW & $\mathrm{DN} / \mathrm{PD}$ & 903 & 606 & 0 & 297 & 0 \\
\hline 106-AW & DN & 532 & 249 & 0 & 198 & 85 \\
\hline 101-AY & $D C$ & 900 & 818 & 0 & 83 & 0 \\
\hline 102-AY & DN & 822 & 790 & 0 & 32 & 0 \\
\hline $101-A Z$ & AGING & 960 & 925 & 0 & 35 & 0 \\
\hline $102-A Z$ & AGING & 951 & 860 & 0 & 91 & 0 \\
\hline $101-S Y$ & CC & 1,121 & 0 & 561 & 0 & 560 \\
\hline $102-S Y$ & DN/PT & 584 & 513 & 0 & 71 & 0 \\
\hline $103-S Y$ & CC & 747 & 170 & 573 & 0 & 4 \\
\hline
\end{tabular}

${ }^{a}$ See next page for description.

Includes interstitial liquid. 
Table 3-1. Double-Shell Tank Inventory as of February 1991. (2 sheets)

\begin{tabular}{|c|c|c|}
\hline $\begin{array}{l}\text { Waste type } \\
\text { abbreviation }\end{array}$ & Waste type & Description \\
\hline Aging & Aging waste & $\begin{array}{l}\text { High-level, first cycle solvent } \\
\text { extraction waste from PUREX (NCAW). }\end{array}$ \\
\hline $\mathrm{CC}$ & $\begin{array}{l}\text { Concentrated } \\
\text { complexant }\end{array}$ & $\begin{array}{l}\text { Concentrated produce from the evaporation } \\
\text { of dilute complexed waste. }\end{array}$ \\
\hline$\overline{C P}$ & $\begin{array}{l}\text { Concentrated } \\
\text { phosphate }\end{array}$ & $\begin{array}{l}\text { Waste originating from the } \\
\text { decontamination of } 100 \mathrm{~N} \text { Area Reactor. } \\
\text { Concentration of this waste produces } \\
\text { concentrated phosphate waste. }\end{array}$ \\
\hline$\overline{D C}$ & Dilute complexed & $\begin{array}{l}\text { Characterized by a high content of } \\
\text { organic carbon including organic } \\
\text { complexants: EDTA, Citric acid, and } \\
\text { HEDTA are the major complexants used. } \\
\text { Main sources of DC waste are saltwell } \\
\text { ? iquid inventory. }\end{array}$ \\
\hline DN & $\begin{array}{l}\text { Dilute } \\
\text { noncomplexed }\end{array}$ & $\begin{array}{l}\text { Low-activity liquid waste originating } \\
\text { from T and S Plants, the } 300 \text { and } \\
400 \text { Areas, PUREX facility (decladding } \\
\text { supernate, ard miscellaneous wastes), } \\
100 N \text { Area (sulfate waste, B Plant, } \\
\text { saltwells, and PFP (supernate). }\end{array}$ \\
\hline DSS & $\begin{array}{l}\text { Double-shell } \\
\text { slurry }\end{array}$ & $\begin{array}{l}\text { Waste evaporated almost to its sodium } \\
\text { aluminate saturation boundary or } \\
6.5 \text { molar hydroxide in the evaporator. } \\
\text { For reporting purposes, DSS is considered } \\
\text { a solid. }\end{array}$ \\
\hline DSSF & $\begin{array}{l}\text { Double-she11 } \\
\text { slurry feed }\end{array}$ & $\begin{array}{l}\text { Waste evaporated just before reaching the } \\
\text { sodium aluminate saturation boundary of } \\
6.5 \text { molar hydroxide in the evaporator. } \\
\text { This form is not as concentrated as } \\
\text { double-shell slurry. }\end{array}$ \\
\hline PN/PD & PUREX decladding & $\begin{array}{l}\text { PUREX Neutralized Cladding Removal Waste } \\
\text { (NCRW) is the solids portion of the PUREX } \\
\text { Facility neutralized cladding removal } \\
\text { waste stream, received in Tank Farms as a } \\
\text { slurry. Classified as TRU waste. }\end{array}$ \\
\hline PT & PFP TRU Solids & TRU solids from 200 West Area operations. \\
\hline
\end{tabular}




\subsubsection{Planned Treatment of Dcuble-Shell Slurry Feed and Double-Shell Slurry}

The DSSF will be pumped from DSTs to the Grout Treatment Facility (GTF) for treatment and conversion into grout. The DSS will be treated in the same manner, except for one additional treatment step to remove the DSS solids from the DSTs.

Milestone M-01-01 of the Tri-Party Agreement calls for the completion of three grout campaigns of DST waste. One campaign of phosphate-sulfate LLW has been completed. The remaining two campaigns will use DSSF and DSS.

Vaults to hold DSSF and DSS grout are under construction. When the vaults are complete, treatment of DSSF and DSS will begin.

Treatment of DSSF-DSS has been studied in the laboratory as part of the Grout Formulation Program to develop and qual ify grout formulae for the solidification of the Hanford Site's DST waste. A formula consists of measured quantities of no more than four dry materials (e.g., calcium carbonate, fly ash, blast-furnace slag, and cement), no more than three liquid additives, and DSSF or DSS waste. The dry materials are blended together and then the liquids are added to the solids.

Qualification consists of verifying grout performance as a function of the following expected precess variabilities:

- Changes in DSSF and DSS waste composition

- Dry material composition variables

- Changes in dry material storage conditions

- Dry material blending variables

- Variables in the mixing of DSSF-DSS waste with the dry blend

- Variables in grout curing conditions

- Changes in the long-term vault conditions (grout aging).

Grout formulation qualifications are expected to be completed in 1992.

\subsection{PLANNED TREATMENT OF NEUTRALIZED CURRENT ACID WASTE}

\subsubsection{Definition of Neutralized Current Acid Waste}

The NCAW is the aqueous high-salt waste from the first-cycle solvent extraction column in the PUREX Plant. This waste is neutralized to prevent corrosion of the tank farm carbon steel tanks.

\subsubsection{Planned Treatment Process of Neutralized Current Acid Waste}

The first step in the proposed treatment process is to separate the solids from the supernatant (Figure 3-1) (WHC 1990). Solid-liquid separation 
WHC-EP-0365-1

Figure 3-1. Neutralized Current Acid Waste Pretreatment and Disposal.

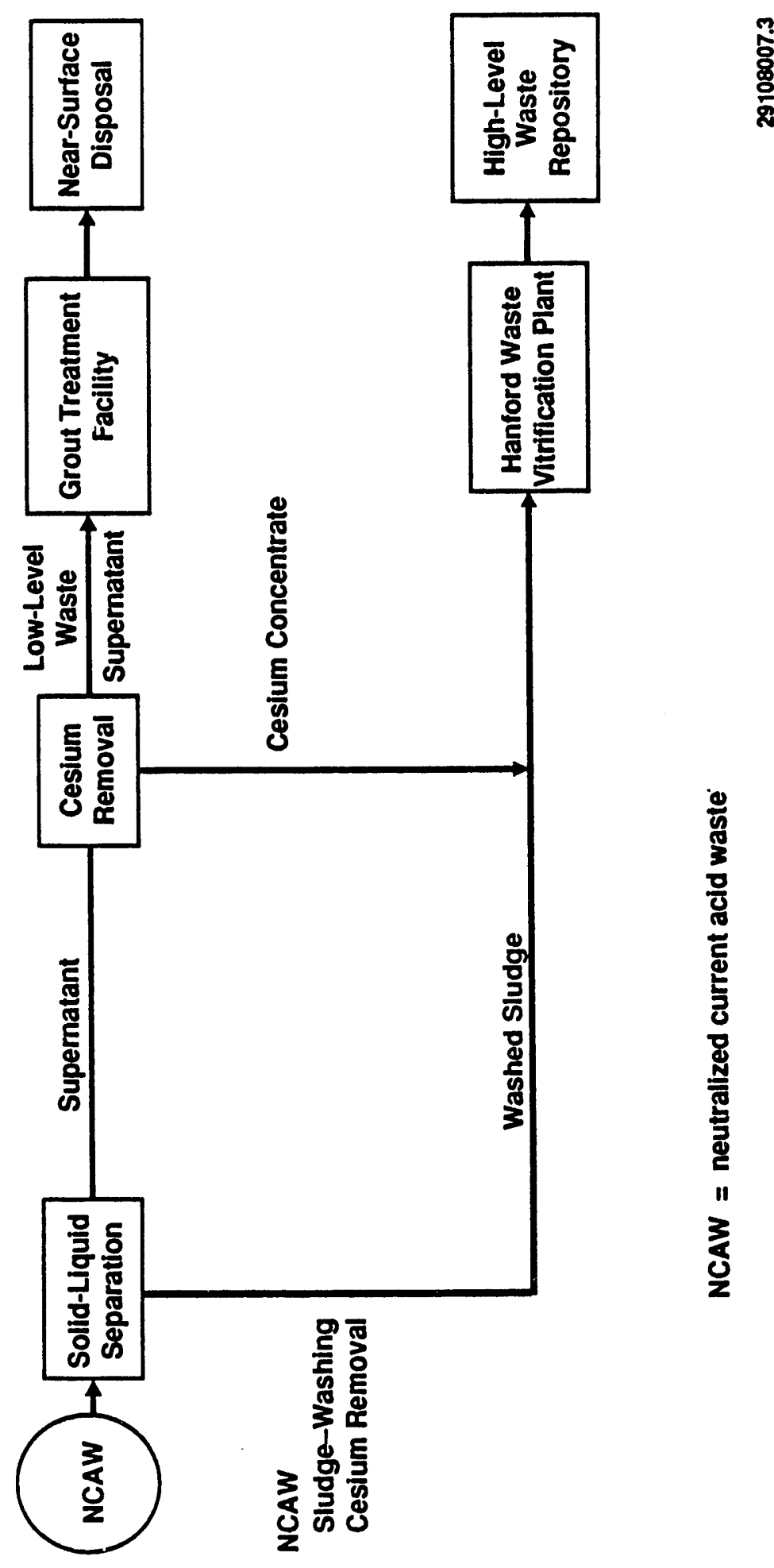


has been demonstrated in the laboratory using a settle-decant process (Wong 1989). The solid-liquid separation step has previously been demonstrated in a plant test.

The supernatant contains most of the cesium that will be removed by ion exchange leaving a LLW fraction destined for the GTF. Cesium will be eluted from the ion-exchange column and combined with the solids, which contains the remaining cesium, to form the HLW fraction of NCAW destined for the HWVP.

\subsubsection{Schedule}

The NCAW treatment technology has been demonstrated in the laboratory. Plant-scale testing in Vault 244-AR and B Plant was scheduled to begin in October 1993; however, as a result of FY 1990 to 1991 funding constraints, the October 1993 date is being revised.

\subsection{PLANNED TREATMENT OF NEUTRALIZED CLADDING REMOVAL WASTE}

\subsubsection{Definition of Neutralized Cladding Removal Waste}

Cladding removal waste (CRW) results from the dissolution of the $N$ Reactor spent-fuel Zircaloy cladding using the Zirflex process in the PUREX reprocessing plant. Neutralization of this waste causes most of the zirconium to precipitate as a hydrated oxide, essentially removing all of the actinides and fission products from the solution. However, sufficient fine plutonium particles are entrained with the precipitated Zirconium that the waste collected in the DSTs is considered to be a transuranic waste. The waste sludge and supernate as stored in the double-shell tanks is known as NCRW.

\subsubsection{Planned Treatment Process of Neutralized Cladding Removal Waste}

The first step in the proposed treatment process is to separate the solids from the supernatant (Figure 3-2). The supernatant is a LLW that can be sent to the GTF for further treatment (Kurath and Yeager 1987).

The remaining solids are washed to remove soluble sodium and potassium compounds. The wash liquids are LLWs that can be sent to the GTF for further treatment. Most of the solids are then dissolved with nitric acid and hydrofluoric acid. The dissolved TRU elements are separated from the undissolved solids and are used as feed for the transuranium extraction (TRUEX) process.

The TRUEX process separates a small volume of the concentrated TRU waste from a large-volume LLW stream, the latter being sent to the GTF. The concentrated TRU stream is recombined with the undissolved solids for transfer to the HWVP for vitrification. 
WHC-EP-0365-1

Figure 3-2. Neutralized Cladding Removal Waste Pretreatment and Disposal.

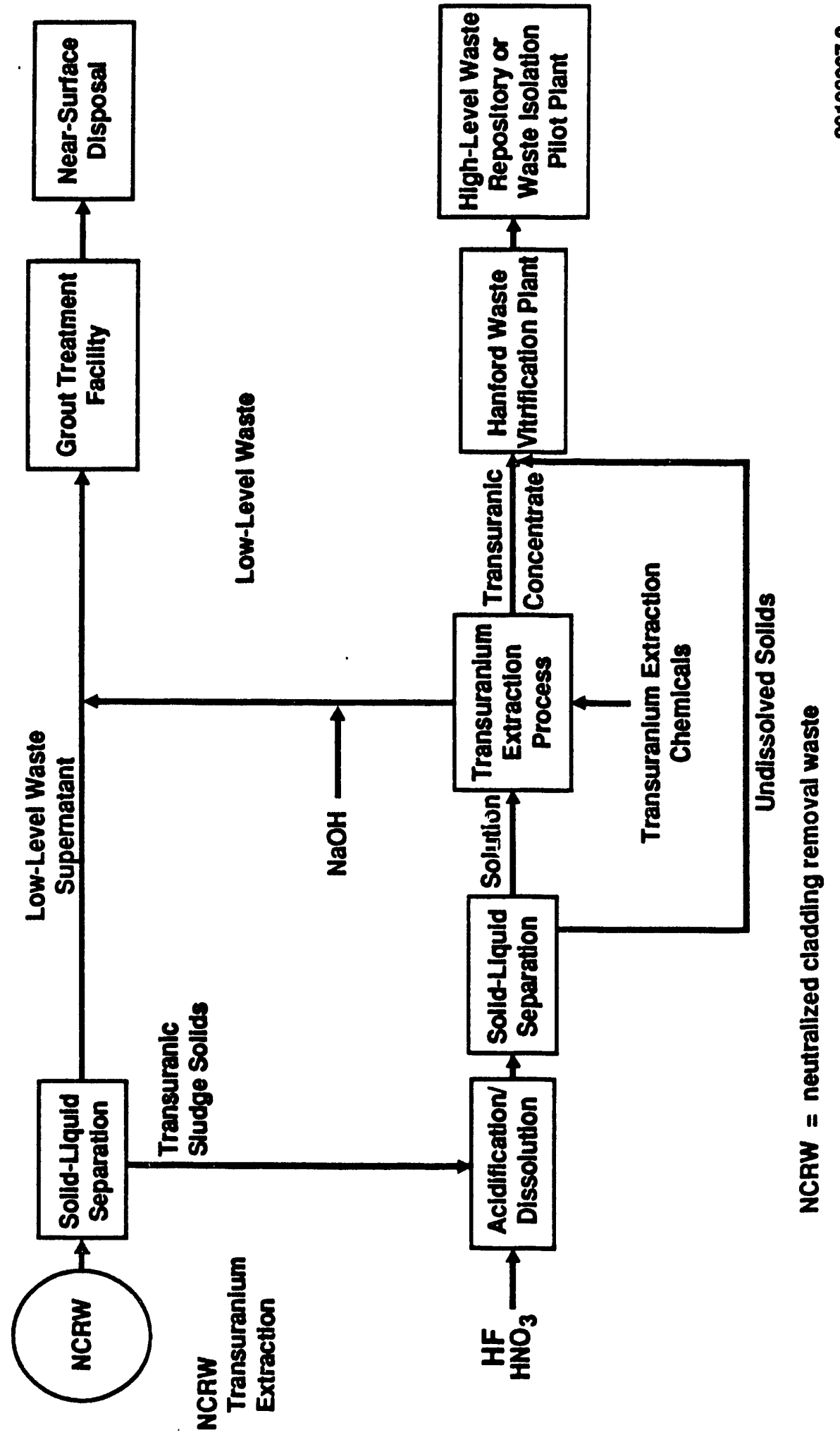




\subsubsection{Schedule}

Pilot plant tests with NCRW are scheduled through FY 1996. Operation of the full-scale TRUEX process using a NCRW feed is currently being studied and a revised schedule will be issued in the future.

\subsection{PLANNED TREATMENT OF PLUTONIUM FINISHING PLANT WASTE}

\subsubsection{Definition of Plutonium Finishing Plant Waste}

The PFP waste originates from the conversion of plutonium nitrate to oxide or metal and includes TRU laboratory wastes. The PFP waste al so includes Plutonium Reclamation Facility (PRF) waste consisting of high-salt solvent extraction waste and organic wash waste.

\subsubsection{Planned Treatment Process of Plutonium Finishing Plant Waste}

The first step in the proposed treatment process is to separate the solids from the supernatant (Figure $3-3$ ). The supernatant is a LLW that can be sent to the GTF for further treatment.

Most of the solids can be dissolved in nitric acid which, when separated from the undissolved solids, becomes the feed for the TRUEX process. The TRUEX process separates a low-volume TRU concentrate siream away from the large-volume LLW stream.

The LLW stream is combined with the LLW supernatant for treatment in the GTF. Tr.e TRU concentrate stream is combined with the undissolved solids for treatment in the HWVP.

\subsubsection{Schedule}

Pilot plant testing of the PFP waste treatment flowsheet is scheduled for FY 1997 with the fuli-scale processing schedule currently being evaluated.

\subsection{PLANNED TREATMENT OF COMPLEXANT CONCENTRATE WASTE}

\subsubsection{Definition of Complexant Concentrate Waste}

Complexant concentrate waste results from concentration of wastes containing large amounts of organic complexing agents. These organic compounds were introduced to the waste during strontium recovery processing in B Plant. 
Figure 3-3. Plutonium Finishing Plant Waste Pretreatment and Disposal.

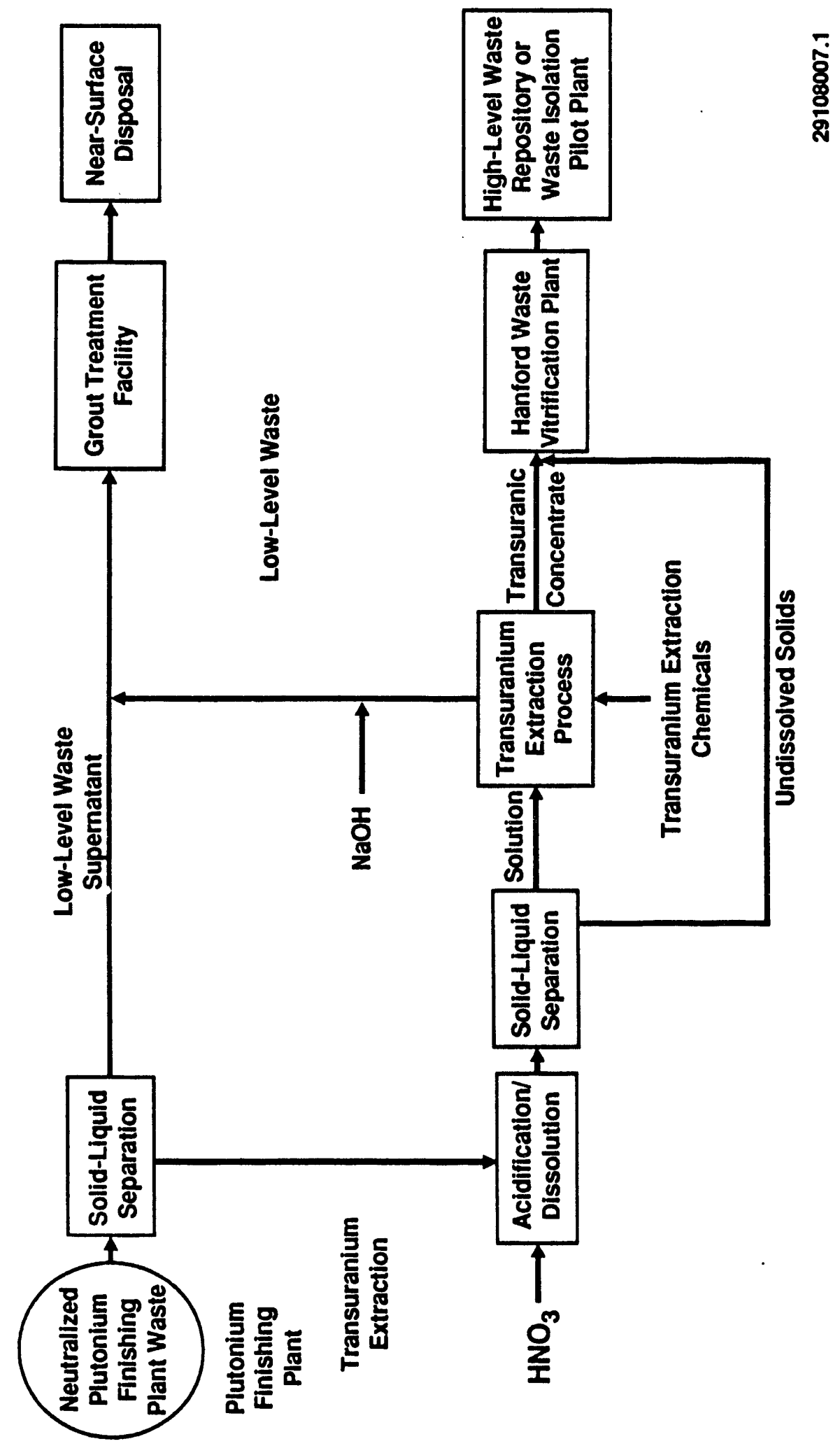




\subsubsection{Planned Treatment Process of \\ Complexant Coricentrate Waste}

The first step in the proposed treatment process is to acidify the CC waste stream to dissolve as many of the solids as possible (Figure 3-4, Kurath 1985, 1986). The liquid is separated from the undissolved solids and used as feed to the TRUEX process. Complexant destruction may be performed before TRUEX processing, but is not required at this step in the treatment.

The TRUEX process separates a low-volume TRU concentrate waste stream from a high-volume LLW stream containing organics and possibly cesium. The TRU concentrate stream is added to the undissolved solids and is treated in the HWVP.

The LLW stream containing organics and cesium undergoes further treatment for organic destruction if not done previously. The LLW is then neutralized and the cesium is removed (Lutton et al. 1980). The resulting LLW stream is sent to the GTF for conversion into grout. The cesium containing stream is sent to the HWVP.

\subsubsection{Schedule}

Pilot plant testing of the CC waste treatment process is scheduled for FY 1997 through FY 1999. The full-scale processing schedule for CC waste is currently being reviewed to evaluate the impact of cesium removal from the low activity portion of the treated waste on the overall treatment of CC wastes.

\subsection{TREATMENT OF WASTE AFTER PRETREATMENT ACTIVITIES}

\subsubsection{Grout Treatment}

Grout treatment is the process of mixing selected DST wastes with groutforming solids, and possibly with liquid chenical additives, to form a grout slurry that is pumped into near-surface lined concrete vaults for solidification and permanent disposal. The waste is characteristically corrosive because of the hydroxide concentration and is characterized as toxic because of the high concentrations of nitrite and hydroxide ion.

The GTF is a treatment facility, and the GDF (which consists of the grout disposal vaults) is considered a disposal facility. The disposal vaults are managed as surface impoundments while grout slurry is fluid and for a period of time after the grout slurry has solidified. The vaults are later closed as landfills.

\subsubsection{Hanford Waste Vitrification Plant}

The HWVP immobilized high-level Hanford Defense Wastes by vitrification. Radioactive waste feed is received from the tank farms, treated with chemicals and concentrated, then mixed with frit and/or glass forming materials. The 
WHC-EP-0365-1

Figure 3-4. Complexant Concentrate Waste Pretreatment and Disposal.

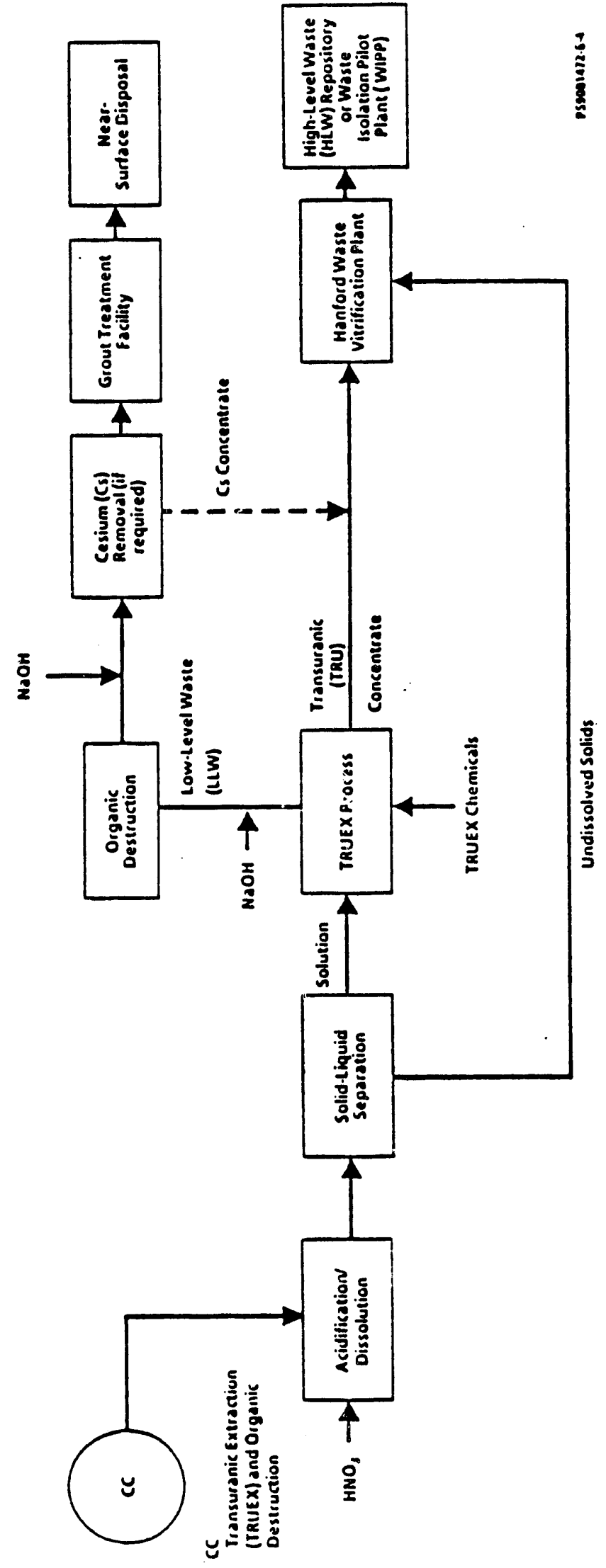


mixture is fed to a joule-heated glass melter. Molten glass product is poured into canisters that are sealed, cleaned, and stored for future shipment to a waste repository.

Eight building structures make up the facility and are utilized to house the vitrification process, glass canister storage, and process/facility supporting systems. Process and storage facilities are designed for a 40 yr life and will remain functional after a design basis accident of earthquake, tornado, fire, or volcanic ash-fall. The facilities provide for remote operation and maincenance of the process with appropriate biological shielding for operator safety. Heating, ventilation, and air conditioning systems provide additional confinement barriers to limit any potential spread of radioactive contaminants.

The vitrification process comprises six major systems, which include the Feed Receipt and Preparation System, Melter System, Off-gas Treatment System, Canister Closure and Decontamination System, Canister Storage System, and the Waste Handling System. These systems are remotely operated and remotely or contact maintained and are located within process cells in the Vitrification Building. Cold Chemical, Utility Systems, and personnel support services required to support the vitrification process are located within buildings adjacent to the Vitrification Building. Wastes from the process and process support operations are treated within the HWVP and nontransuranic wastes are discharged outside of the HWVP to the underground Waste Holding Tank.

The current baseline HWVP startup date is FY 1999 with cold startup testing the prior year (FY 1998). None of the waste generated during cold startup testing will be transferred to tank farms.

The canisters of glass produced in HWVP will be stored in a storage facility until a repository is available.

\subsection{SUMMARY OF DOUBLE-SHELL TANK WASTE TREATMENT}

Studies have been performed to evaluate alternative processes arid facilities for treatment of DST wastes before final disposal. A 1989 study confirmed the technical and economic incentives for partitioning the waste into a large, low-level fraction suitable for near-surface disposal and a smaller fraction of TRU waste and/or HLW that must be immobilized by solidification in glass (Kupfer et al. 1989).

An evaluation of alternative facilities for performing waste treatment processes and optimum schedules for timely completion of the DST waste disposal mission was completed in 1990. The evaluation defined the existing baseline waste treatment plan for DST waste.

- Separate NCAW sludges from supernatant liquids and wash the sludge with water to remove soluble salts.

- Remove TRU waste components from acidified wastes using the TRUEX process. This technology is being developed for application with NCRW, PFP waste, and CC waste. 
- Remove radiocesium from alkaline NCAW and CC supernatant liquors.

- Destroy the complexant in CC waste to remove complexed TRU elements and provide a feed for near-surface disposal.

An experimental program is being conducted to obtain process information in the areas of sludge retrieval, solvent extraction feed stability, dissolver residue compositions, and stimulant properties. These areas of interest are summarized below.

- Investigations to evaluate the amount of nitrogen oxides liberated in the NCRW pretreatment process.

- The composition of the dissolver residue, the primary feed to the HWVP, was more completely characterized. This information will permit the HWVP glass composition to be better predicted.

- Investigations to evaluate the processibilty of the various layers of sludge within the tanks.

- Investigations of the stream that will be fed to the HWVP found that the NCRW pretreatment process added significant amounts of phosphate to this stream from the stripping agent used in the TRUEX process. As a result, initial studies are reported that investigated alternate stripping agents for the TRUEX process.

A design base experiment was performed (Swanson 1991) which confirmed the applicability of the dissolution/TRUEX process for pretreating Nr?W. The design base experiment was based on the expected flowsheet, which is essentially the current flowsheet, but without washing of the NCRW sludge. The experiment demonstrated that $95 \%$ of the waste materials end up as a LLW, while more than $99 \%$ of the transuranics end up in the HWVP feed.

An evaluation of the suitability of B Plant for the processing of DST wastes has been undertaken in FY 1991. Early in the year questions were brought forward which addressed the ability of B Plant to meet the Washington State Administrative Code (WAC) and which addressed materials of construction issues for the TRUEX treatment plant. A large effort is under way to resolve the WAC and corrosion issues. This activity is also intended to create a new baseline for the treatment of Hanford Site wastes that incorporates WAC issues, corrosion issues, HWVP construction and operations issues, and some preliminary single-shell tank treatment issues.

Accomplishments in FY 1990 and in the beginning of FY 1991 include:

- Completed the conceptual design report for the pilot-scale facility for demonstrating the TRUEX process with actual DST wastes.

- Ozone-ultraviolet light methods for organic complexant destruction were found to be less effective at complexant destruction than the use of hydrogen peroxide. 
Additional waste treatability tasks that are in progress or expected to be initiated in FY 1991 are described below. Documentation describing the results of these studies will be provided in future annual reports.

- Continue laboratory-scale tests to assess the application of the TRUEX process to remove TRU components from acidic solutions of actual NCRW, PFP waste, and CC waste.

- Proceed with the detailed design of the TRUEX pilot plant.

- Continue laboratory-scale tests of complexant destruction methods. Efforts will focus on hydrogen peroxide-ultraviolet light, and supercritical water oxidation.

- Provide updated preliminary conceptual flowsheets for the TRUEX process for pretreatment of NCRW, PFP waste, and CC waste.

- Perform capacity tests of candidate ion-exchange resins for removal of ${ }^{137} \mathrm{Cs}$ from aikàline waste. 
WHC-EP-0365-1

\subsection{TREATMENT OF EXISTING SINGLE-SHELL WASTES}

This section documents the studies, activities, and issues which occurred in this area over the period of March 1, 1991, through February 28, 1991.

\subsection{DESCRIPTION OF SINGLE-SHELL TANK WASTES}

One hundred and forty-nine SSTs contain portions of HLW, TRU waste, and LLW produced during Hanford Site operations before 1980. The current waste inventory of the SST system as of February 1991 is given in Table 4-1, which is taken from the Tank Farm Surveillance and Waste Status Summary Report for February 1991. Interim stabilization efforts are currently underway (Hanton 1991) to remove pumpable liquid from the SSTs leaving saltcake, sludge, and interstitial liquid. This supports Tri-Party Agreement Interim Milestone M-05-09. The remaining SST contents form the bases for future treatment efforts.

\subsection{TREATMENT OF SINGLE-SHELL TANK WASTES}

Two treatinent alternatives are being considered: in situ treatment and treatment after retrieval.

The ultimate goal of the in situ treatment alternative is to treat and stabilize the waste so that there is not a need for retrieval of the waste. However, in situ treatment as a part of a retrieval option is not being ruled out.

The treatment-after-retrieval alternative has two goals: (1) minimize the volume of waste fed to the HWVP while meeting current HWVP specifications, and (2) maximize the fraction of nonradioactive chemica] compounds routed to GTF while meeting the non-TRU $(<100 \mathrm{nCi} / \mathrm{g}),{ }^{90} \mathrm{Sr}$, and ${ }^{137} \mathrm{Cs}$, concentration requirements for the solidified grout. The processes for treatment of the retrieved SST waste are currently based on the processes and equipment developed for the DST program: sludge washing, TRUEX, cesium ion exchange, and possibly complexant destruction. Treatment technologies specific to SST waste are being studied and funded by the DOE Environmental Restoration (EM-40) Program and the Office of Technology Development (EM-50) Program, including the OTO Underground Storage Tank/Integrated Demonstration (UST/ID).

In July 1990, the "Third Party Technical Workshop--Hanford Site SingleShell Tank Waste and Residuals" was held in Spokane, Washington (McLaughi in et al. 1990). The objective of the workshop was to identify, discuss, and rate innovative technologies that have not been seriously explored for treatment of SST waste and residuals. Nationally-recognized waste management experts presented ideas on how to treat SST waste either "in situ" (treat in place) or "ex situ" (remove and treat). The objective of this initiative was to assist in partially fulfilling a milestone to identify an appropriate means of disposing of waste, tanks, contaminated piping, and soils. A total of 11 ex situ and 11 in situ applied technologies with potential applicability to SST waste and residuals were identified and discussed in the workshop. An additional 12 innovative technologies were also identified. 
Table 4-1. Single-Shell Tank Inventory as of February 1991. (5 sheets)

\begin{tabular}{|c|c|c|c|c|c|}
\hline \multirow{2}{*}{$\begin{array}{l}\text { Tank } \\
\text { No. }\end{array}$} & \multirow{2}{*}{$\begin{array}{c}\text { Waste } \\
\text { material }\end{array}$} & \multicolumn{4}{|c|}{ Volume in kgal } \\
\hline & & $\begin{array}{l}\text { Total } \\
\text { waste }\end{array}$ & Supernatant & Sludge & Saltcake \\
\hline $101-A$ & DSSF & 953 & 0 & 3 & 950 \\
\hline $102-A$ & DSSF & 41 & 4 & 15 & 22 \\
\hline $103-A$ & DSSF & 370 & 4 & 366 & 0 \\
\hline 104-A & NCPLX & 28 & 0 & 28 & 0 \\
\hline $105-A$ & NCPLX & 19 & 0 & 19 & 0 \\
\hline $106-A$ & $\mathrm{CP}$ & 125 & 0 & 125 & 0 \\
\hline $101-A X$ & DSSF & 748 & 0 & 3 & 745 \\
\hline $102-A X$ & CC & 39 & 3 & 7 & 29 \\
\hline $103-A X$ & CC & 112 & 0 & 2 & 110 \\
\hline $104-A X$ & NCPLX & 7 & 0 & 7 & 0 \\
\hline $101-B$ & NCPLX & 113 & 0 & 113 & 0 \\
\hline $102-B$ & NCPLX & 32 & 4 & 18 & 10 \\
\hline $103-B$ & NCPLX & 59 & 0 & 59 & 0 \\
\hline $104-B$ & NCPLX & 371 & 1 & 301 & 69 \\
\hline $105-B$ & NCPLX & 306 & 0 & 40 & 266 \\
\hline $106-B$ & NCPLX & 117 & 1 & 116 & 0 \\
\hline $107-B$ & NCPLX & 165 & 1 & 164 & 0 \\
\hline $108-B$ & NCPLX & 94 & 0 & 94 & 0 \\
\hline 109-B & NCPLX & 127 & 0 & 127 & 0 \\
\hline $110-B$ & NCPLX & 246 & 1 & 245 & 0 \\
\hline $111-B$ & NCPLX & 237 & 1 & 236 & 0 \\
\hline $112-B$ & NCPLX & 33 & 3 & 30 & 0 \\
\hline 201-B & NCPLX & 29 & 1 & 28 & 0 \\
\hline 202-B & NCPLX & 27 & 0 & 27 & 0 \\
\hline 203-B & NCPLX & 51 & 1 & 50 & 0 \\
\hline 204-B & NCPLX & 50 & 1 & 49 & 0 \\
\hline $101-B X$ & NCPLX & 43 & 1 & 42 & 0 \\
\hline $102-B X$ & NCPLX & 96 & 0 & 96 & 0 \\
\hline $103-B X$ & NCPLX & 66 & 4 & 62 & 0 \\
\hline 104-BX & NCPLX & 99 & 3 & 96 & 0 \\
\hline $105-B X$ & NCPLX & 51 & 5 & 43 & 3 \\
\hline $106-B X$ & NCPLX & 46 & 15 & 31 & 0 \\
\hline $107-B X$ & NCPLX & 345 & 1 & 344 & 0 \\
\hline 108-BX & NCPLX & 26 & 0 & 26 & 0 \\
\hline $109-B X$ & NCPLX & 193 & 0 & 193 & 0 \\
\hline $110-B X$ & NCPLX & 199 & 1 & 189 & 9 \\
\hline 111-BX & NCPLX & 230 & 19 & 68 & 143 \\
\hline $112-B X$ & NCPLX & 165 & 1 & 164 & 0 \\
\hline
\end{tabular}


Table 4-1. Single-Shell Tank Inventory as of February 1991. (5 sheets)

\begin{tabular}{|c|c|c|c|c|c|}
\hline \multirow{2}{*}{$\begin{array}{l}\text { Tank } \\
\text { No. }\end{array}$} & \multirow{2}{*}{$\begin{array}{c}\text { Waste } \\
\text { materiala }\end{array}$} & \multicolumn{4}{|c|}{ Volume in kgal } \\
\hline & & $\begin{array}{l}\text { Total } \\
\text { waste }\end{array}$ & Supernatant & Sludge ${ }^{b}$ & Saltcake \\
\hline 101-BY & NCPLX & 387 & 0 & 109 & 278 \\
\hline 102-BY & NCPLX & 432 & 15 & 0 & 417 \\
\hline 103-BY & NCPLX & 400 & 0 & 5 & 395 \\
\hline 104-BY & NCPLX & 406 & 0 & 40 & 366 \\
\hline 105-BY & NCPLX & 503 & 0 & 44 & 459 \\
\hline 106-BY & NCPLX & 642 & 0 & 95 & 547 \\
\hline 107-BY & NCPLX & 266 & 0 & 60 & 206 \\
\hline 108-BY & NCPLX & 228 & 0 & 154 & 74 \\
\hline 109-BY & NCPLX & 474 & 33 & 87 & 354 \\
\hline $110-B Y$ & NCPLX & 398 & 0 & 103 & 295 \\
\hline 111-BY & NCPLX & 459 & 0 & 21 & 438 \\
\hline 112-BY & NCPLX & 291 & 0 & 5 & 286 \\
\hline $101-C$ & NCPLX & 88 & 0 & 88 & 0 \\
\hline $102-C$ & NCPLX & 427 & 3 & 424 & 0 \\
\hline $103-C$ & NCPLX & 195 & 133 & 62 & 0 \\
\hline $104-C$ & CC & 295 & 0 & 295 & 0 \\
\hline $105-C$ & NCPLX & 150 & 0 & 150 & 0 \\
\hline $106-C$ & NCPLX & 229 & 32 & 197 & 0 \\
\hline $107-C$ & NCPLX & 337 & 0 & 337 & 0 \\
\hline $108-C$ & NCPLX & 66 & 0 & 66 & 0 \\
\hline $109-C$ & NCPLX & 66 & 4 & 62 & 0 \\
\hline $110-C$ & NCPLX & 201 & 5 & 196 & 0 \\
\hline $111-C$ & NCPLX & 57 & 0 & 57 & 0 \\
\hline $112-C$ & NCPLX & 104 & 0 & 104 & 0 \\
\hline $201-C$ & NCPLX & 2 & 0 & 2 & 0 \\
\hline $202-C$ & EMPTY & 1 & 0 & 1 & 0 \\
\hline $203-C$ & NCPLX & 5 & 0 & 5 & 0 \\
\hline $204-C$ & NCPLX & 3 & 0 & 3 & 0 \\
\hline $101-S$ & NCPLX & 427 & 12 & 244 & 171 \\
\hline $102-S$ & DSSF & 549 & 0 & 4 & 545 \\
\hline $103-5$ & DSSF & 248 & 17 & 10 & 221 \\
\hline $104-S$ & NCPLX & 294 & 1 & 293 & 0 \\
\hline $105-S$ & NCPLX & 456 & 0 & 2 & 454 \\
\hline $106-S$ & NCPLX & 543 & 0 & 32 & 511 \\
\hline $107-S$ & NCPLX & 368 & 6 & 293 & 69 \\
\hline $108-5$ & NCPLX & 604 & 0 & 4 & 600 \\
\hline $109-5$ & NCPLX & 568 & 0 & 13 & 555 \\
\hline $110-5$ & NCPLX & 692 & 0 & 131 & 561 \\
\hline $111-5$ & NCPLX & 596 & 10 & 139 & 447 \\
\hline
\end{tabular}


Table 4-1. Single-Shell Tank Inventory as of February 1991. (5 sheets)

\begin{tabular}{|c|c|c|c|c|c|}
\hline \multirow{2}{*}{$\begin{array}{l}\text { Tank } \\
\text { No. }\end{array}$} & \multirow{2}{*}{$\begin{array}{c}\text { Waste } \\
\text { material }\end{array}$} & \multicolumn{4}{|c|}{ Volume in kgal } \\
\hline & & $\begin{array}{l}\text { Total } \\
\text { waste }\end{array}$ & Supernatant & Sludge ${ }^{b}$ & Saltcake \\
\hline $112-5$ & NCPLX & 637 & 0 & 6 & 631 \\
\hline $101-S X$ & $D C$ & 456 & 1 & 112 & 343 \\
\hline $102-5 x$ & DSSF & 543 & 0 & 117 & 426 \\
\hline $103-5 x$ & NCPLX & 667 & 32 & 112 & 523 \\
\hline $104-5 x$ & DSSF & 614 & 0 & 136 & 478 \\
\hline $105-5 x$ & DSSF & 683 & 0 & 73 & 610 \\
\hline $106-5 x$ & NCPLX & 538 & 61 & 12 & 465 \\
\hline $107-5 x$ & NCPLX & 104 & 0 & 104 & 0 \\
\hline $108-5 x$ & NCPLX & 115 & 0 & 115 & 0 \\
\hline $109-5 x$ & NCPLX & 250 & 0 & 250 & 0 \\
\hline $110-5 x$ & NCPLX & 62 & 0 & 62 & 0 \\
\hline $111-5 x$ & NCPLX & 125 & 0 & 125 & 0 \\
\hline $112-5 x$ & NCPLX & 92 & 0 & 92 & 0 \\
\hline $113-5 x$ & NCPLX & 26 & 0 & 26 & 0 \\
\hline $114-5 x$ & NCPLX & 181 & 0 & 181 & 0 \\
\hline $115-S x$ & NCPLX & 12 & 0 & 12 & 0 \\
\hline $101-T$ & NCPLX & 133 & 30 & 103 & 0 \\
\hline $102-\mathrm{T}$ & NCPLX & 32 & 13 & 19 & 0 \\
\hline $103-\mathrm{T}$ & NCPLX & 27 & 4 & 23 & 0 \\
\hline 104- T & NCPLX & 445 & 3 & 442 & 0 \\
\hline $105-\mathrm{T}$ & NCPLX & 98 & 0 & 98 & 0 \\
\hline $106-\mathrm{T}$ & NCPLX & 21 & 2 & 19 & 0 \\
\hline $107-T$ & NCPLX & 180 & 9 & 171 & 0 \\
\hline $108-T$ & NCPLX & 44 & 0 & 44 & 0 \\
\hline 109-T & NCPLX & 58 & 0 & 58 & 0 \\
\hline 110-T & NCPLX & 379 & 3 & 376 & 0 \\
\hline $111-T$ & NCPLX & 458 & 2 & 456 & 0 \\
\hline $112-\mathrm{T}$ & NCPLX & 67 & 7 & 60 & 0 \\
\hline 201- $T$ & NCPLX & 29 & 1 & 28 & 0 \\
\hline 202-T & NCPLX & 21 & 0 & 21 & 0 \\
\hline 203-T & NCPLX & 35 & 0 & 35 & 0 \\
\hline 204-T & NCPLX & 38 & 0 & 38 & 0 \\
\hline 101-TX & NCPLX & 87 & 3 & 84 & 0 \\
\hline 102-TX & NCPLX & 113 & 0 & 0 & 113 \\
\hline 103-TX & NCPLX & 157 & 0 & 157 & 0 \\
\hline 104-TX & NCPLX & 65 & 1 & 0 & 64 \\
\hline 105-TX & NCPLXX & 609 & 0 & 0 & 609 \\
\hline $106-\mathrm{TX}$ & NCPLX & 453 & 0 & 0 & 453 \\
\hline
\end{tabular}


Table 4-1. Single-Shell Tank Inventory as of February 1991. (5 sheets)

\begin{tabular}{|c|c|c|c|c|c|}
\hline \multirow{2}{*}{$\begin{array}{l}\text { Tank } \\
\text { No. }\end{array}$} & \multirow{2}{*}{$\begin{array}{c}\text { Waste } \\
\text { material }\end{array}$} & \multicolumn{4}{|c|}{ Volume in kgal } \\
\hline & & $\begin{array}{l}\text { Total } \\
\text { waste }\end{array}$ & Supernatant & Sludge & Saltcake \\
\hline $107-T X$ & NCPLX & 36 & 1 & 0 & 35 \\
\hline 108-TX & NCPLX & 134 & 0 & 0 & 134 \\
\hline 109-TX & NCPLX & 384 & 0 & 0 & 384 \\
\hline $110-T X$ & NCPLX & 462 & 0 & 0 & 462 \\
\hline $111-T X$ & NCPLX & 370 & 0 & 0 & 370 \\
\hline $112-T X$ & NCPLX & 649 & 0 & 0 & 649 \\
\hline $113-T X$ & NCPLX & 607 & 0 & 0 & 607 \\
\hline $114-T X$ & NCPLX & 535 & 0 & 0 & 535 \\
\hline 115-TX & NCPLX & 640 & 0 & 0 & 640 \\
\hline $116-T X$ & NCPLX & 631 & 0 & 0 & 631 \\
\hline $117-\mathrm{TX}$ & NCPLX & 626 & 0 & 0 & 626 \\
\hline 118-TX & NCPLX & 347 & 0 & 0 & 347 \\
\hline $101-T Y$ & NCPLX & 118 & 0 & 118 & 0 \\
\hline $102-T Y$ & NCPLX & 64 & 0 & 0 & 64 \\
\hline $103-T Y$ & NCPLX & 162 & 0 & 162 & 0 \\
\hline $104-T Y$ & NCPLX & 46 & 3 & 43 & 0 \\
\hline $105-T Y$ & NCPLX & 231 & 0 & 231 & 0 \\
\hline 106-TY & NCPLX & 17 & 0 & 17 & 0 \\
\hline $101-U$ & NCPLX & 25 & 3 & 22 & 0 \\
\hline $102-U$ & NCPLX & 374 & 18 & 43 & 313 \\
\hline $103-U$ & NCPLX & 468 & 13 & 32 & 423 \\
\hline $104-U$ & NCPLX & 122 & 0 & 122 & 0 \\
\hline $105-U$ & NCPLX & 418 & 37 & 32 & 349 \\
\hline $106-U$ & NCPLX & 226 & 15 & 26 & 185 \\
\hline $107-U$ & DSSF & 406 & 31 & 15 & 360 \\
\hline $108-U$ & NCPLX & 468 & 24 & 29 & 415 \\
\hline $109-U$ & NCPLX & 463 & 19 & 48 & 396 \\
\hline $110-U$ & NCPLX & 186 & 0 & 186 & 0 \\
\hline $111-U$ & DSSF & 329 & 0 & 26 & 303 \\
\hline $112-U$ & NCPLX & 49 & 4 & 45 & 0 \\
\hline $201-U$ & NCPLX & 5 & 1 & 4 & 0 \\
\hline $202-U$ & NCPLX & 5 & 1 & 4 & 0 \\
\hline $203-U$ & NCPLX & 3 & 1 & 2 & 0 \\
\hline $204-U$ & NCPLXX & 3 & 1 & 2 & 0 \\
\hline
\end{tabular}


Table 4-1. Single-Shell Tank Inventory as of February 1991. (5 sheets)

\begin{tabular}{|c|c|c|}
\hline $\begin{array}{l}\text { Waste type } \\
\text { abbreviation }\end{array}$ & Waste type & Description \\
\hline$C C$ & $\begin{array}{c}\text { Concentrated } \\
\text { complexant }\end{array}$ & $\begin{array}{l}\text { Concentrated product from } \\
\text { the evaporation of dilute } \\
\text { complexed waste. }\end{array}$ \\
\hline$C P$ & $\begin{array}{l}\text { Concentrated } \\
\text { phosphate }\end{array}$ & $\begin{array}{l}\text { Waste originating from the } \\
\text { decontamination of } \\
100 \mathrm{~N} \text { Reactor. Concentra- } \\
\text { tion of this waste produces } \\
\text { concentrated phosphate } \\
\text { waste. }\end{array}$ \\
\hline$D C$ & $\begin{array}{l}\text { Dilute } \\
\text { complexed }\end{array}$ & $\begin{array}{l}\text { Characterized by a high } \\
\text { content of organic carbon } \\
\text { including organic } \\
\text { complexants: EDTA, Citric } \\
\text { acid, HEDTA, IDA, being the } \\
\text { major complexants used. } \\
\text { Main sources of DC waste } \\
\text { are saltwell liquid } \\
\text { inventory. }\end{array}$ \\
\hline DSSF & $\begin{array}{l}\text { Double-shell } \\
\text { slurry feed }\end{array}$ & $\begin{array}{l}\text { Waste evaporated just } \\
\text { before reaching the sodium } \\
\text { aluminate saturation } \\
\text { boundary of } 6.5 \text { molar } \\
\text { hydroxide in the } \\
\text { evaporator. This form is } \\
\text { not as concentrated as } \\
\text { double-she11 slurry. }\end{array}$ \\
\hline NCPLX & Noncomplexed & $\begin{array}{l}\text { General waste term applied } \\
\text { to all Hanford Site liquors } \\
\text { not identified as } \\
\text { complexed. }\end{array}$ \\
\hline $\begin{array}{l}\text { EDTA = } \\
\text { HEDTA }= \\
\text { IDA = }\end{array}$ & nodiacetate & $\begin{array}{l}\text { Saacetic acid } \\
\text { aminetriacetic ac }\end{array}$ \\
\hline
\end{tabular}




\subsection{STATUS OF SINGLE-SHELL TANK WASTE TREATMENT STUDIES}

The following information provides the status of SST waste treatment activities completed and/or in progress. As noted, some of the development activities listed are being funded by and for the DST program.

\subsubsection{Destruction of Complexant Concentrate Waste}

Research in the area of the destruction of $C C$ waste was funded through the DST program and applies to the destruction of CC waste in the DSTs. However, the developing technology may have application to the variety of CC waste that may be in the SSTs (Winters 1981).

Laboratory experiments are being performed with ultraviolet peroxide oxidation, sonication with and without peroxide, and refluxing peroxide oxidation on synthetic solutions.

\subsubsection{Removal of Transuranic Components by the TRUEX Process}

Research into the possibility of removing the TRU components was funded by the DST program for application to DST waste. The technology developed to remove the TRU waste content of the DST wastes may have direct application to treatment of SST waste. Technology development plans for FY 1991 include laboratory testing of TRUEX on simulated SST waste.

\subsubsection{The Strontium Extraction Process}

A new process is being developed for the extraction and recovery of ${ }^{90} \mathrm{Sr}$ from acidic nuclear waste streams. It is called the strontium extraction (SREX) process.

The funding for this research effort has been phased out by the DST program and is being funded by the OTD SST program. The Argonne National Laboratory (ANL) is performing the research to explore processes for the recovery of ${ }^{90} \mathrm{Sr}$ and possibly ${ }^{37} \mathrm{Cs}$ from acidic liquid HLW (Horwitz et al. 1990).

The new SREX process (based on a crown ether) has been demonstrated to be an effective and selective solvent extraction process. Continued research is necessary to determine its feasibility. Items to investigate include, but are not necessarily limited to, entrainment losses, radiation effects on the process solvent, and the extraction behavior of other fission products. Future work is expected to include extractions from simulated Hanford Site SST waste and actual waste both in the laboratory and pilot plant if SREX performance warrants further work. 


\subsection{LITERATURE AND LABORATORY STUDIES}

Many pretreatment processes require dissolution of the sc? ids before processing. The potential dissolution reagents and procedures for Hanford Site SST sludge are being evaluated by Westinghouse Hanford.

Westinghouse Hanford and PNL are currently conducting laboratory tests to evaluate sludge dissolution methods recommended above. This testing program will include nitrate destruction methods which reduce the amount of nitrite and nitrate (nitrates). Nitrates are estimated to make up 60 to $80 \%$ of the Hanford Site SST waste. The objective of this test program will be to develop an integrated process for pretreatment of retrieved waste in preparation for the final waste form. The processes ultimately developed will be commensurate with plant-sized operations.

Simulated waste will be formulated from Hanford Site SST waste analyses reports such as the sampling and analysis report of tanks 102-C, 105-C, and 106-C (Thomas et al. 1991). Simulated waste will be utilized in initial scoping tests at the Hanford Site and other sites until actual SST waste is available and demonstration with actual tank waste is warranted.

\subsection{TECHNOLOGY PROGRAM PLANS}

The required technology, resources, equipment, program funding, and proposed plans for closure of the six SST operable units were documented (KIem et al. 1990). The operable units comprise treatment, storage, and disposal units (wastes, tanks, and soil contaminated by leaks) and postpractice units (ancillary units and soil contaminated by spills). The plan includes the following functions: technical integration, characterization, stabilization and isolation, regulatory documents, retrieval, pretreatment, final waste package preparation, long-term isolation, and Resource Conservation and Recovery Act (RCRA) postpractice units.

These functions represent a set of actions proposed to become the framework for planning as the program transitions from development to implementation. The functions are divided into main elements of subfunctions and related tasks. Descriptions, special assumptions and constraints, projected costs, and schedules were developed to quantify the requirements and provide a baseline for future planning.

This technology program plan was revised (Opitz 1991) and expanded to 12 subtasks to support DOE and programmatic goals and meet the requirements of the Tri-Party Agreement (Ecology et al. 1990). Systems engineering became one of the 12 major tasks in the Characterization and Assessment Program (CAP), and quality engineering is described separately in the technology program plan like the other tasks.

A new task, field investigation and characterization, is intended to support the characterization needs of the RCRA past-practices tasks. The overall intent of this document is to provide a plan, task description, and list of resource requirements of ER. 


\subsection{SYSTEMS ENGINEERING STUDY}

A baseline of the functional requirements that will guide the conceptual design and development of SST system closure facilities was prepared (Boomer et a1. 1991). The functional requirements baseline is part of the larger systems engineering study. These requirements provide a framework for closure alternative selection. The plan will update this baseline to incorporate new technology as it is identified, developed, and demonstrated and as the range of alternatives is narrowed.

Based on the functional requirements, a draft systems engineering study addressing the closure of SST waste was prepared (Boomer et a1. 1990) proposing the technical basis to select the method for closure of the SSTs. This systems engineering study develops several conclusions that include a recommended alternative for closure characterization requirements, schedule, interim waste stabilization, development requirements, facility requirements, and integration of DST and SST waste processing. 
WHC-EP-0365-1

This page intentionally left blank. 
WHC-EP-0365-1

\subsection{EVALUATION AND SELECTION OF GROUT}

This section documents the studies, activities, and issues which occurred in this area over the period of March 1, 1990, through February 28, 1991.

Cement-based grouts are extensively used in the U.S. and worldwide as a venicle for immobilization and near-surface disposal of solid and liquid LLWs. Formal. selection of cementitious grout for disposal of selected liquid wastes in near-surface vaults was made in the Hanford Waste Management Plan (DOE-RL 1983). This selection was strongly influenced by the generally favorable Oak Ridge Natiunal Laboratory (ORNL) site grout hydrofracture disposal experience and by the Savannah River Laboratory (SRL) site evaluation and selection of grout waste form for the disposal of certain aqueous LLW salt solutions. This selection was supported by an independent, comprehensive evaluation performed by Hanford Site scientists and engineers in 1980. This evaluation showed grout to be preferred over other known forms for immobilization and bulk disposal of Hanford Site liquid LLWs (RHO 1980).

The grout formulation process involves waste sampling, characterization, and product testing to ensure that the grout will meet strength and leachability criteria.

\subsection{REGULATORY CHANGES AFFECTING GROUT}

In June 1990, the EPA promulgated major changes to Title 40 of the Code of Federal Regulations, Part 268 ( 40 CFR 2.58), "Land Disposal Restrictions" (EPA 1991). This part sets Land Disposal fiestriction (LDR) standards and treatment methods. The EPA has not delegated LDR enforcement authority to Ecology.

As a result of the revision to 40 CFR 268, a Grout LDR Management Plan has been written (Hendrickson 1991). The plan describes the process used to determine if potential grout waste feeds are LDR. The plan also discusses grout feed waste designations of concern and lists treatment technologies. If a grout waste feed is determined to be prohibited from land disposal, either a Best Demonstrated Available Technology (BDAT) assessmont for treatment of the waste must be performed or a treatability variance must be granted. Should a waste candidate fail to be acceptable for grout disposal subsequent to these actions, the waste must be pretreated prior to land disposal as a grout.

In January 1991 the U.S. Nuclear Regulatory Commission (NRC) published Rev. 1 of the Technical Position on Waste Furm (NRC 1991). Although the Hanford Grout Disposal Program is not subject to NRC regulation, the program has historically followed NRC guidance. The most significant change in this revision is that the NRC now recommends a mean compressive strength of $3,450 \mathrm{kPa}\left(500 \mathrm{lb} / \mathrm{in}^{2}\right)$ for cementitious waste forms. Previous guidance was $60 \mathrm{lbf} / \mathrm{in}^{2}$ (to ensure solidification and structural stability). The NRC recommends that "maximum practical compressive strengths" be attained and suggests $500 \mathrm{lbf} / \mathrm{in}^{2}$ to provide some margin of safety against long-term degradation. Compressive strengths of Hanford Site grouts have ranged from 300 to over 1,400 ibf $/ i^{2}$. This document may infiuence the grout formulation. 
In March 1991 Ecology released a revision to WAC 173-303, "Dangerous Waste Regulations" (Ecology 1991). This revision specifies the Toxicity Characteristic Leaching Procedure (TCLP) as the required test for toxicity. The TCLP replaces Extraction Procedure Toxicity (EP Tox) testing. This change has had virtually no effect on the test results with respect to grout performance.

\subsection{NEW ACTIVITIES}

Grout Reformulation--The Hanford grout vaults will dissipate heat relatively slowly because of the layers of asphalt and soil surrounding them. As a result, a low heat generating formulation is desirable. The current grout formulation contains calcium carbonate, which was added as a diluent to reduce the heat evolved durir.g hydration. This formulation has resulted in poorer quality grouts with increased amounts of drainable liquid, which must be recycled for ultimate reprocessing, while not entirely eliminating the heat problem.

In February 1991 meetings were held with Westinghouse Hanford, ORNL, and PNL grout experts to plan a grout reformulation effort. The ORNL is currently examining dry blend material candidates that do not include calcium carbonate. The PNL is examining acidic pretreatment of the 106-AN waste feed to reduce the heat liberated from the hydration of species containing aluminum in the waste feed. Subsequent efforts will explore the impact of the anticipated composition changes upon grout properties. Several promising formulation candidates will receive extensive testing to ensure flexibility in case some problem be found with the chosen formulation.

Double-Shell Tank Waste Sampling--Waste in candidate double-shell tanks is sampled using the bottle-on-a-string method to determine the compatibility of tank waste with grout specifications. Double-shel1 tanks 241-AP-102 and 241-AP-104 (102-AP and 104-AP respectively) are the dedicated grout feed tanks. If after sampling and analys is the waste in a candidate double-shell tank is acceptable, it will be transferred to either tank 102-AP or tank 104-AP. Once transferred to tank 102-AP or tank 104-AP, the waste is sampled again to verify earlier results prior to grouting.

At a minimum, the waste in tank 106-AP will be sampled. This dilute waste is a candidate for blending with concentrated waste for eventual disposal in a grout vault. Tanks 104-AN (candidate) and 102-AP may also be sampled during FY 1991.

Core Sampling--The Phosphate/Sulfate Waste (PSW) vault, where pouring was completed in July 1989, will be core sampled to verify quality and to evaluate nondestructive testing methods.

Cold-Cap Formulation--The Army Corps. of Engineers is working to develop a cold-cap formilation for the PSW vault. It is expected that the same cold-cap formulation will be suitable for subsequent vaults. A final report is expected by September 1991. 


\subsection{STATUS OF ACTIVITIES IN PROGRESS}

Grout Treatment Facility Dangerous Waste Permit--The permit application underwent a comprehensive review in May 1991. Changes have been incorporated and the document will undergo a final review. The document will enter the Westinghouse Hanford/DOE Field Office, Richland, certification process in August. Ecology will be notified in writing as to the submittal date (expected in September 1991).

Final Safety Analysis Report--Revision B of the document will undergo functional review beginning in August. Revision 0 will be sent for review in January. The document is scheduled to be issued in June 1992.

Performance Assessment--The Performance Assessment of Grouted DoubleShe 11 Tank Waste at Hanford has been transmitted to DOE-HQ for review. This document is required by DOE Order 5820.2A.

Vault Construction--As of June 1991 Vault 102 will be ready for the spray-on liner to be applied to the interior of the vault. After the liner is applied, Vault 102 will be filled with water to check for leaks (hydrotest). The final concrete pour on Vault 105 should be completed in June 1991. Fabrication on vault cover panels has been initiated.

The vault diffusion barrier design verification testing is intended to be completed at the University of California at Berkeley. Test results should be available before the scheduled date for installation of the barrier around the sides of Vault 102 .

\subsection{ESTIMATE OF PLANNED WORK ACTIVITIES FOR 1992}

Readiness Review--The Hanford Grout Disposal Program will undergo Westinghouse Hanford and DOE Field Office, Richland, readiness review before startup.

Double-Shell Tank Waste Sampling--Tanks 104-AN and 102-AP will be sampled if sampling is not conducted in 1991. Tanks 105-AN and 104-AP will be sampled. Waste in candidate DSTs will be sampled using the bottle-on-a-string method.

Vault Equipment--Mobile vault exhausters, excess liquid pumps, and two Portable Instrument Houses (PIHs) will be procured in 1992. One PIH is needed for each operational vault to supply power to exhausters, run thermocouple dataloggers, etc.

Quality Verification--The Hanford Mobile Solidified Low-Level Radioactive Waste Sampling Unit will be fabricated for the purpose of coring grout vaults. 
WHC-EP-0365-1

This page intentionally left blank.

$5-4$ 


\subsection{EVALUATION AND SELECTION OF BOROSILICATE GLASS}

\subsection{INTRODUCTION}

The United States has selected borosilicate glass as the waste form of choice for use in disposing of high-level nuclear waste currently stored in tanks at three DOE sites; Savannah River Site, West Valley Demonstration Project, and the Hanford Site. For the Hanford Site this decision pertained specifically to the disposal of the high-level waste currently stored in DSTs (DOE 1988). Projects are underway at each of these three sites to establish vitrification process facilities.

This section focuses on accomplishments and plans related to (1) the DOE acceptance specifications for the borosilicate waste form and (2) HWVP activities for waste form compliance.

\subsection{FISCAL YEAR 1991 WASTE FORM QUALIFICATION ACTIVITIES}

A major development of the past year was the DOE revision of the 1986 Waste Acceptance Preliminary Specifications (WAPS) for vitrified high-level Waste Forms (DOE 1986). The HWVP project was called upon to contribute to this revision effort. Previous versions of the WAPS were site specific; the draft revision is now generic relative to the range of borosilicate glass waste forms that the three sites will produce. The WAPS are currently undergoing final review and clearance by the DOE. It should be noted that WAPS are specifically the responsibility of the DOE Office of Civilian Radioactive Waste Management (i.e., the program that manages and directs the geologic repository investigation for the disposal of high-level nuclear waste).

In response to the requirements imposed by the WAPS, the HWVP project is currently working on a revision of the Waste Form Qualification (WFQ) Program $\mathrm{Pl}$ an and an outline of the Waste Compliance Plan. Collectively these documents will describe the activities that must be accomplished, e.g., design, technology and preoperational testing, in order to ensure that the HWV will produce a product that meets the WAPS and thus is acceptable for final disposal. It should be noted that the HWVP project routinely evaluates, for possible application to the HWVP, the accomplishments of the other two vitrification projects since they are generally farther along in development.

Other significant WFQ-related progress by the HWVP project during FY 1991 included the following:

- A revision of the Waste Form and Canister Description Document (WFCD) (Colburn 1991) was issued.

- Additional testing of borosilicate glasses to identify the acceptable bounds of composition relative to satisfying both WFQ and processing requirements. 
- A computerized mathematical model was constructed to enable target (i.e., proposed product) formulations and properties to be predicted from the three basic feed inputs to the HWVP process (i.e., waste, glass frit, and recycle). Correlations between glass composition and glass properties that are being developed as part of the first activity are an integral part of this modeling work.

\subsection{FISCAL YEAR 1992 WASTE FORM QUALIFICATION ACTIVITIES}

The WFQ Program Plan will be issued, and a draft of the Waste Compliance Plan (WCP) will be prepared for review within the HWVP project. The WCP will focus on describing the means by which the HWVP will comply with the waste acceptance specifications. Glass testing and correlation refinement will continue relative to the definition of the acceptable glass composition envelope per both processing and WFQ requirements. Model development and error analysis work will continue in support of developing the process/product control system for the HWVP. 


\section{WHC-EP-0365-1}

\subsection{ALTERNATIVE TREATMENT/DISPOSAL TECHNOLOGY}

This section documents the studies, activities, and issues which occurred in this area over the period of March 1, 1990, through February 28, 1991.

The Underground Storage Tank Integrated Demonstration, funded by the DOE Office of Technology Development, will be examining alternative technologies and technology systems for waste treatment and disposal as part of the overall remediation of DOE mixed waste tanks. The Integrated Demonstration was in the planning stage in FY 1991. 
WHC-EP-0365-1

This page intentionally left blank. 


\subsection{SAFETY ISSUES}

This section documents the studies, activities, and issues which occurred in this area over the period of March 1, 1990, through February 28, 1991.

\subsection{DESCRIPTION OF TANK WASTE SAFETY ISSUES}

This section provides an overview of four of the safety issues associated with SSTs and DSTs and their potential impact on treatment. Issues of concern to potential treatment strategies include cyclic hydrogen (flammable gas mixture) release, ferrocyanide accumulation, the presence of organic chemical mixed with nitrate-nitrite salts, and the requirement to add cooling water to single-shell tank 106-C.

Safety issues are the primary present focus of the Waste Tank Safety Program whose task is to ensure the safety of the SST and DST systems unti1 appropriate treatment and disposal of their contents can take place. To ensure interim safety, extensive management and technical controls are employed so that the safety-issue related tanks (Table 8-1) continue to be maintained in a safe manner. In addition, there is an ongoing requirement for broad-based peer review of all planning and safety documentation by high-level groups established for that purpose by the U.S. Department of EnergyHeadquarters (DOE-HQ). Approval by DOE-HQ of all actions relating to the flammable gas and ferrocyanide tanks before intrusive acts is also required.

The hazardous characteristics of the existing wastes, leading to their identification and control, are estimated on the basis of general information from the chemical literature, expert peer judgment, and limited historical and actual sampling data. Mitigating factors, such as moisture content, presence of inert diluents (e.g., sodium carbonate, sodium aluminate, and/or sodium phosphate) and conditions that could lead to a lack of reactivity of the wastes, were purposely understated.

Scenarios of significant concern associated with waste in tanks include the following.

- Potential for ignition of flammable gases, such as hydrogen-air, hydrogen-nitrous oxide.

- Potential for ignition of organic-nitrate mixtures initiated by the radiolytic or chemical heating of dry saltcake or by localized heating.

- Potential for ignition of ferrocyanide-nitrate mixtures initiated by the radiolytic or chemical heating of dry saltcake or by localized heating.

- Potential for a leak in tank causing release of contaminants into the environment while having to meet a requirement to add cooling water to that tank to maintain its structural integrity. 
Administrative and technical controls are in place to restrict activities which could cause undesirable exothermic reactions. For example, pumping of interstitial liquid from ferrocyanide tanks has been stopped to maintain present moisture levels, thermal conductivity, and heat capacities. Nonsparking tools and use of electrical bonding techniques on instrumentation are used around hydrogen tanks. So-called "normal" activities for tanks at issue are limited to surveillance. Special safety analysis documents, which are extensively reviewed by peers, are prepared for all work inside the tank.

In addition, comprehensive monitoring, characterization, and applied research efforts have been initiated to support resolution of issues and to prevent creation of future problems associated with potentially incompatible wastes or actions related to the planned treatment and disposal of the wastes in these storage tanks. Such efforts will also provide the basis for safe near-future remediation of tanks and define the envelope of safety to support the disposal of all high-activity waste in the Hanford Site tanks. A review of these and other safety issues was recently presented at Waste Management-91 (Babad 1991a).

\subsection{FLAMMABLE GAS GENERATING TANKS}

One DST, tank 241-SY-101 generates, stores, and periodically releases significant quantities of flammable gases, primarily hydrogen and nitrous oxide. If a spark were to be present, this gas could ignite and burn, potentially causing filters in the vent system to fail with resulting spread of contamination. Tank 241-SY-101 was identified as an unreviewed safety question.

Flammable gas generation in tank 101-SY is a top priority waste tank safety issue at the Hanford Site because average peak concentrations above the lower flammability limit (LFL) for hydrogen occur periodically. Such venting of gases is expected to keep reoccurring until some form of remediation is taken. During the episodic venting, the tank is sometimes brought to positive pressure for a few minutes by the rapidity of the gas release. In addition, it is likely that a greater-than-LFL concentration exists at times within the waste. In the unlikely event an ignition source were present during these periods, a hydrogen burn or explosion could occur with a possible release of nuclear waste to onsite and offsite personnel.

There are 22 other tanks also suspected of potentially containing smaller accumulations of hydrogen or other flammable gases. There is, however, a significant difference in severity between those tanks and tank 101-SY. Evidence of venting, surface level behavior, and knowledge of the other tank contents suggests a much lower likelihood of potentially dangerous gas concentrations in these other tanks.

The goal of the flammable gas program is to gain sufficient understanding by peers of the causes and patterns of gas generation to allow DOE to either mitigate or remediate the hazardous situation. It is expected that some of the 23 flammable gas-generating tanks will prove to be inherently safe and will not require further action. 


\subsection{TANKS CONTAINING FERROCYANIDE}

Twenty-four tanks contain insoluble ferrocyanide salts in quantities greater than 1,000 g-mol mixed in a sodium nitrate/sodium nitrite matrix. This mass is the threshold quantity of concern. If subjected to high temperatures, above $545^{\circ} \mathrm{F}$, these materials could become explosive. However, there is a low probability for any heating mechanism to occur.

Ferrocyanide tanks were identified as an unreviewed safety question since it is not known whether concentrations and distribution of ferrocyanide and nitrate-nitrite materials in the tanks would allow an uncontrolled exothermic reaction or explosion if tank contents were allowed to heat up. Although the measured tank temperatures are far below the temperature required to cause an exothermic reaction, the consequences of an event could be at a level potentially exceeding the safety envelope defined in the Environmental Impact Statement (EIS) (EIS 1987, GAO 1990).

Ferrocyanide salts in the presence of nitrate and/or nitrite constituents can be made to react and explode under certain conditions, which include dryness, favorable stoichiometry, and elevated temperatures, or a high-energy spark. These exothermic reactions can start to take place in the range of 180 to $200^{\circ} \mathrm{C}\left(356\right.$ to $\left.392^{\circ} \mathrm{F}\right)$, and an explosion can occur at $285^{\circ} \mathrm{C}\left(545^{\circ} \mathrm{F}\right)$. The maximum temperature measured inside the ferrocyanide tanks at the Hanford Site is at or below $57{ }^{\circ} \mathrm{C}\left(135^{\circ} \mathrm{F}\right)$. Records at the Hanford Site currently show that there are 24 SSTs that contain appreciable ferrocyanide precipitates (1,000 g-mol or greatior). The ferrocyanide content of the tanks ranges from 1,000 g-mol (465 lb) up to approximately 200,000 g-mol (93,000 1b) in tank BY-104 calculated as the ferrocyanide anion. Other wastes in these tanks probably include significant quantities of sodium nitrate and sodium nitrite; a variety of silicate, aluminate, hydroxide, phosphate, sulfate, carbonate, and nitrate salts; as well as salts or oxides of uranium, copper, and calcium. In addition, fission products are also present from the processing of irradiated fuel. Some tanks may also contain quantities of organic materials that cause exothermic reactions to start at the low end of the temperature range listed above.

The probability of a ferrocyanide explosion during storage is considered very low because currently measured maximum temperatures in the ferrocyanide tanks $\left[57^{\circ} \mathrm{C}\left(135^{\circ} \mathrm{F}\right)\right]$ falls significantly below the lowest threshold temperature 180 to $200{ }^{\circ} \mathrm{C}\left(356\right.$ to $392^{\circ} \mathrm{F}$ ) for ferrocyanide nitrate-nitrite reactions found in the laboratory. Administrative controls are in place to ensure that actions are avoided that could lead to creation of temperature rises in the tank. Efforts are focused on enhancing monitoring capability, characterizing tank 104-BY, and gaining information on the mechanism and propagation and radionuclide release characteristics of a ferrocyanide explosion.

A recent review (Babad 1991a, 1991b) of the practice of pumping liquid out of SSTs to avoid potential leakage of radioactive and hazardous materials into the soil disclosed that additional analysis of this practice for the ferrocyanide tanks is needed. For tanks that contain large quantities of ignitable materials (tanks containing ferrocyanide and organics) such pumping has been discontinued until safety evaluations of liquid removal can be 
completed. Verifying that the interstitial and supernatant liquid can be safely removed from tanks containing ferrocyanide is a key part of meeting the agreements set forth in the Tri-Party Agreement.

\subsection{TANKS CONTAINING ORGANIC WASTE}

Eight single-shell tanks contain organic chemical salts at concentrations believed to be greater than $10 \mathrm{~mol} \%$ sodium acetate equivalent mixed in a sodium nitrate-sodium nitrite matrix, a mixture that is potentially reactive at temperatures above $392^{\circ} \mathrm{F}$. Two of the hydrogen and one of the ferrocyanide tanks also appear on the organic list.

Concentrations of organics may be present in some tanks that could cause an exothermic reaction given a sufficient driving force, such as high temperature. However, the difference between ignition temperatures and actual tank temperatures measured, as discussed previously for the ferrocyanide tanks, is great enough ( $135^{\circ} \mathrm{F}$ vs. $392^{\circ} \mathrm{F}$ ) that the probability of such a reaction is considered very low. The consequences of the postulated reaction is about the same as that for some scenarios for an explosion in a "burping" hydrogen tank. Although work on this issue is just beginning, consideration of hazards associated with heating nitrate-nitrite mixtures containing organic materials is an integral part of both the hydrogen and ferrocyanide tank efforts.

High concentrations of organic compounds have been inferred (from tank transfer, flowsheet records, and limited analytical data) in eight SSTs. Many organic chemicals, if present in concentrations above $10 \mathrm{dry}$ wt\% (sodium acetate equivalent), have the potential to react with nitrate-nitrite constituents at temperatures above $200{ }^{\circ} \mathrm{C}\left(392^{\circ} \mathrm{F}\right)$ in an exothermic manner. The concentrations of organic materials in the 1 isted SSTs and their chemical identity is not accurately known at present. The organic chemicals used at the Hanford Site production plants and support operations have been identified by Klem (1990a). A tank sampling program is being developed to provide more information on the contents of these tanks and to serve as a basis for laboratory testing and safety evaluations.

These tanks were identified as safety concerns on the premise that literature information suggested that mixtures of organic chemical and sodium nitrate and sodium nitrite could deflagrate at temperatures above $200{ }^{\circ} \mathrm{C}$ $\left(392^{\circ} \mathrm{F}\right)$. Initial small-scale work (Beitel 1976) on organic-nitrate reactions performed in the past suggests that waste mixtures containing more then 10 wt\% (dry salt basis) of nitrite-nitrate organic mixture are safe at temperatures below $200{ }^{\circ} \mathrm{C}\left(392^{\circ} \mathrm{F}\right)$.

Additional work is planned to better define the initiation point for the organic-nitrate reactions. Work is also planned to demonstrate that in-tank temperature measurements are representative of the tank contents. Even with the removal of most free liquids (and possible attendant decrease in thermal conductivity), temperatures in the SSTs will be maintained below that necessary for an uncontrolled reaction. In-tank temperatures are stable or decreasing and have been for several years. The measured in-tank temperatures of the organic SSTs are approximately $110^{\circ} \mathrm{C}$ (equivalent to $230^{\circ} \mathrm{F}$ ) and below the laboratory observed minimum exotherm initiation temperatures. 
Evaluation of the records of material transfers to the remaining SSTs and DSTs continues and may uncover additional tanks that meet the organic concentration requirements, placing them on "issue list" status.

\subsection{HIGH-HEAT TANK}

One tank requires periodic addition of water and forced air ventilation to maintain its temperature within the permissible limits determined by structural considerations. Tank 241-106-U was identified as a safety concern.

Single-shell tank 106-C (530,000-gal capacity) has been used for radioactive waste storage since mid-1947 and currently contains about $250,000 \mathrm{gal}$ of waste. During the late $1960 \mathrm{~s}$, a program to recover strontium and cesium from aging stored waste in the $A$ and $A X$ tank farms started at the Hanford Site. Sludge washing/decanting steps in this process were not as efficient as planned and resulted in the transfer of heat-generating strontium-rich sludge to tank 106-C.

Water addition is required to provide evaporative cooling and prevent structural damage to tank 106-C. This tank is currently considered to be sound. If the current methods of cooling tank 106-C are stopped, the sludge will heat to temperatures greater than established tank limits and may cause tank structural problems. The temperature limits are $300^{\circ} \mathrm{F}$ for sludge, and $250^{\circ} \mathrm{F}$ for the dome air space (OSD-T-151-00013). The tank generates enough heat that water is periodically added to prevent overheating. This is an anomaly among the SSTs. In the event of a leak, the need for cooling water to be added to the tank would remain. Existing interstitial liquid could not be removed from the tank, in accordance with existing practice, to prevent unacceptable leakage to the environment.

\subsection{POTENTIAL IMPACT ON TREATMENT}

Extensive requirements for peer review and associated approvals for any intrusive action in listed tanks (Table 8-1) could impact both cost and schedule associated with treatment of tank wastes. In addition, the existence of potentially incompatible mixtures of chemicals, in the tanks will impose temperature limitations on the retrieval operations and might require modification of pretreatment flowsheets to either destroy reactive components or to require separation of fuel from oxidizers.

The waste tank safety program has recommended that temperature limitations be imposed on all aspects of retrieval to 1 imit edge-of-tool temperatures to below $150{ }^{\circ} \mathrm{C}\left(302{ }^{\circ} \mathrm{F}\right)$. As work progresses the program will determine the degree to which the listed tanks do indeed pose a near-term or inherent safety problem with respect to safe storage. Many of the mitigation and/or remediation strategies that are being evaluated for tank 101-SY, should be broadly applicable to other tank wastes. The focus for the ferrocyanide program is more clearly defined as an envelope of risk for an explosion of heated tank wastes. The organic program planning effort is just beginning. Remediation alterative for tank 106-C are being evaluated. 
Table 8-1. Safety Issue Tanks.

\begin{tabular}{|c|c|c|c|}
\hline $\begin{array}{c}\text { Flammable-gas } \\
\text { generating }\end{array}$ & Ferrocyanide & Organic & High heat \\
\hline$\frac{\text { Single-shell }}{101-\mathrm{A}}$ & Single-shell & Single-shell & $\frac{\text { Single-shell }}{106-C}$ \\
\hline $\begin{array}{l}101-A \\
101-A X\end{array}$ & $\begin{array}{l}10<-B X \\
106-B X\end{array}$ & $103-B$ & \\
\hline 103-AX & $110-B X$ & $105-T X$ & \\
\hline $102-S$ & $111-B X$ & $118-T X$ & \\
\hline $111-5$ & 101-BY & $102-5$ & \\
\hline $112-5$ & 103-BY & $106-5 x$ & \\
\hline $101-5 x$ & 104-BY & $106-U$ & \\
\hline $102-5 x$ & 105-BY & $106-U$ & \\
\hline $103-5 x$ & 106-BY & & \\
\hline $104-5 x$ & 107-BY & & \\
\hline $105-5 x$ & $108-B Y$ & & \\
\hline $106-5 x$ & $110-B Y$ & & \\
\hline $109-5 x$ & 111-BY & & \\
\hline 110-T & 112-BY & & \\
\hline $103-U$ & $108-C$ & & \\
\hline $105-U$ & $109-C$ & & \\
\hline $108-J$ & $111-C$ & & \\
\hline $109-U$ & $112-C$ & & \\
\hline Double-shel1 & $107-T$ & & \\
\hline & 118-TX & & \\
\hline 103-AN & $101-T Y$ & & \\
\hline 104-AN & 103-TY & & \\
\hline $105-A N$ & 104-TY & & \\
\hline 101-SY & & & \\
\hline $103-S Y$ & & & \\
\hline
\end{tabular}

NOTE: The underlined tanks also appear on either the flammable gases or ferrocyanide lists.

The program is actively working with both the SST and DST treatment and disposal programs to ensure that all engineering approaches accommodate the potential risk associated with the watch list tanks. 


\subsection{REFERENCES}

Augustine, C. A., 1989 (January), Double-Shell Tank Waste Dis,posal Integration Plan, WHC-EP-0229, Revision 1, Westinghouse Hanford Company, Richland, Washington.

Babad, H., J. L. Deichman, 1991a, Hanford High-Activity Waste Tank Safety Issues, WHC-SA-1017-FP, Westinghouse Hanford Company, Richland, Washington.

Babad, H., J. L. Deichman, D. D. Wodrich, 1991b, "Hanford High-Activity Waste Tank Safety Issues," WHC-SA-1215-FP, Westinghouse Hanford Company, Richland, Washington.

Bechtold, D. B., K. D. Fowler, and A. L. Pragnano, 1991, Report on Laboratory Tests of Organic Destruction in Acidified Complexant Concentrate, WHC-SD-CP-TR-003, Westinghouse Hanford Company, Richland, Washington.

Beitel, G. A., 1976, Chemical Stability of Salt Cake in the Presence of Organic Materials, ARH-LD-119, Atlantic Richfield Hanford Company, Richland, Company.

Boomer, K. D., J. S. Garfield, K. A. Giese, B. A. Higley, J. S. Layman, A. L. Boldt, N. R. Croskrey, C. E. Goldberg, L. J. Johnson, and R. J. Parazin, 1990 (June), Functional Requirements Baseline for the Closure of Single-Shell Tanks, WHC-EP-0338, Westinghouse Hanford Company, Richland, Washington.

Boomer, K. D., S. K. Baker, A. L. Boldt, M. C. Britton, J. D. Galbraith, J. S. Garfield, K. A. Giese, C. E. Golberg, B. A. Higley, K. J. Hull, L. J. Johnson, R. P. Knight, J. S. Layman, R. S. Marusich, R. J. Parazin, M. G. Piepho, E. J. Slaathaug, T. L. Waldo, and C. E. Worcester, 1991, Systems Engineering Study for the Closure of Single-Shell Tanks, Wirc-EP-0405, Draft A, Westinghouse Hanford Company, Richland, Washington.

Colburn, R. P., 1991, Hanford Waste Vitrification Plant Preliminary Waste Form and Canister Description - Fiscal Year 1990 Update, WHC-EP-0376, Westinghouse Hanford Company, Richland, Washington.

DOE, 1982, U.S. Department of Energy, Environmental Assessment-Waste Form Selection for SRP High-Level Waste, U.S. Department of Energy Report DOE/EA 00179, Washington, D.C.

DOE, 1986, Waste Acceptance Preliminary Specifications for the Defense Waste Processing Facility High-Level Waste Form, OGR/B-8, U.S. Department of Energy, Office of Civilian Radioactive Waste Management, Washington, D.C.

DOE, 1988, Disposal of Hanford Defense High-Level Transuranic and Tank Wastes, Hanford Site, Richland, Washington, Federal Register, Vol. 53, No. 72, pp. 12449-12453, U.S. Department of Energy, Washington, D.C.

DOE-RL, 1983, Hanford Waste Management Plan, U.S. Department of Energy, Richland Operations Office, Richland, Washington. 
Ecology, 1991 (March), "Dangerous Waste Regulations," Washington Department of Ecology, Olympia, Washington.

EIS, 1987, Final Environmental Impact Statement Disposal of Hanford Defense High-Level, Transuranic and Tank Wastes, Hanford Site, Richland, Washington, DOE/EIS-0113, U.S. Department of Energy, December 1987.

EPA, 1990 (June), Code of Federal Regulations, Title 40, Part 268 (40 CFR 268), "Land Disposal Restrictions," U.S. Environmental Protection Agency, Washington, D.C.

GAO, 1990 Consequences of Explosion of Hanford's Single-Shell Tanks Are Understated, United States General Accounting Office, October 1990 , (GA0/RCED-91-34).

Hanford Federal Facility Agreement and Consent Order, Washington State Department of Ecology, 01 ympia, Washington; U.S. Environmental Protection Agency, Region 10, Seattle, Washington; and U.S. Department of Energy, Richland, Washington (May 1989).

Hanion, B. M., 1991, Tank Farm Surveillance and Waste Status Summary Report for March 1991, WHC-EP-0182-36, Westinghouse Hanford Company, Richland, Washington.

Hendrickson, 1991 (Apri1), Grout Treatment Facility Land Disposal Restriction Management Plan, WHC-SD-WM-PIn-005 Rev. 1, Westinghouse Hanford Company, Richland, Washington.

Horwitz, E. P., M. L. Dietz, and D. E. Fisher 1990, SREX: A New Process for the Extraction and Recovery of Strontium from Acidic Nuclear Waste Streams, Argonne National Laboratory, Argonne, Illinois.

Jantzen, C. M., 1990, Nuclear Waste Product Consistency Test Method Version 3.0, WSRC-TR-90-539, Savannah River Laboratory, November 1990.

Klem, M. J., C. E. Go oerg, R. D. Givvy, K. A. Giese, F. A. Ruck, J. C. Sonnichsen, D. U. Wanner, N. R. Wing, K. A. Woodworth, and J. F. Fletcher, 1990 (June), Single-Shell Tank Systems Technical Support Program Plan, WHC-EP-0288, Westinghouse Hanford Company, Richland, Washington.

Klem, M. J., C. E. Goldberg, R. D. Gibby, K. A. Giese, F. A. Ruck, J. C. Sonnichsen, D. D. Wanner, N. R. Wing, K. A. Woodworth, and J. F. Fletcher, 1990 (June), Single-Shell Tank Systems Technical Support Program P1an, WHC-EP-0288, Westinghouse Hanford Company, Richland, Washington.

Kupfer, M. J., A. L. Boldt, and J. L. Buelt, 1989 (September), Process and Facility Options for Pretreatment of Hanford Tank Waste, SD-WM-TA-015, Revision 0, Westinghouse Hanford Company, Richland, Washington.

Kurath, D. E., 1985 (June), Technology Study for the Pretreatment of Complexant Concentrate, SD-WM-TA-010, Revision 0, Rockwei i Hanford Operations, Richland, Washington. 
Kurath, D. E., 1986 (January), Technology Program Plan for the Pretreatment of Complexant Concentrate, SD-WM-TPP-018, Revision 0, Rockwell Hanford Operations, Richland, Washingtun.

Kurath, D. E., and C. J. Yeager, 1987 (May), Integrated Technology Program Plan for the Treatment of NCRW, SD-WM-TPP-036, Revision 1, Rockwel1 Hanford Operations, Richland, Washington.

Lutton, T. W., W. W. Schulz, D. M. Strachen, and L. J. Bollyky, 1980 (March), Ozonation of Hanford Nuclear Defense Waste, RHO-SA-98, Rockwell Hanford Operations, Richiand, Washington.

McLaughlin, T. J., D. A. Lamar, and S. J. Phillips, 1990 Innovative Technologies and Unit Operations Available for Potential In Situ and Ex Situ Treatment of Waste and Residuals for Hanford Single-Shell Tanks, WHC-SA-0999-FP, Westinghouse Hanford Company, Richland, Washington.

NRC, 1991 (January), Technical Position on Waste Form, Rev. 1, U.S. Nuclear Regulatory Commission, Washington, D.C.

Opitz, B. E., 1991, Single-Shell Tank Systems-Technical Support Program Plan, WHC-EP-0288, Westinghouse Hanford Company, Richland, Washington.

RHO, 1980 (October), Technical Aspects of Long-Term Management Alternatives for High-Level Defense Waste at the Hanford Site, RHO-LD-141, Rockwel1 Hanford Operations, Richland, Washington.

Schulz, W. W., M. M. Beary, S. A. Gallagher, B. A. Higley, R. G. Johnston, F. M. Jungfleisch, M. J. Kupfer, R. A. Palmer, R. A. Watrous, and G. A. Wolf, 1980 (September), Preliminary Evaluation of Alternatives for Immobilization of Hanford High-Level Defense Wastes, RHO-ST-32, Rockwell Hanford Operations, Richland, Washington.

Schwoebel, R. L., and C. J. Northrup, 1978 (November), Proceedings of the Sandia Laboratories Workshop on the use of Titanate Ion Exchangers for Defense Waste Management, SAND78-2019, Sandia National Laboratory, Albuquerque, New Mexico.

Swanson, J. L., 1991, Use of the TRUEX Process for the Pretreatment of Neutralized Cladding Removal Waste (NCRW) Sludge-Results of a Design Basis Experiment, PNL-7734, Pacific Northwest Laboratory, Richland, Washington.

Thomas, D. L., F. T. Hara, J. H. Kaye, R. T. Steele, R. W. Stromatt, and M. W. Urie, 1991 (February), SST Sample Characterization Analysis of Archive Samples 102-C, 105-C, and 106-C, PNL-7258, Pacific Northwest Laboratory, Richland, Washington.

WHC, 1990a, Annual Report of Tank Waste Treatability, WHC-EP-0365, Westinghouse Hanford Company, Richland, Washington.

WHC, $1990 \mathrm{~b}$ (January), Assessment of Double-Shell Tank Waste Pretreatment Options, WHC-SP-0̂464, Revision 1 , Westinghouse Hanford Company, Richiand, Washington. 
Winters, W. I., 1981 (June), Effect of pH on the Destruction of Complexants with Ozone in Hanford Nuclear Waste, RHO-SA-203, Rockwell Hanford Operations, Richland, Washington.

Wong, J. J., 1989 (October), 244-AR Conceptual Flowsheet for Processing of NCAW, WHC-SE-WM-TI-396, Revision 0, Westinghouse Hanford Company, Richl and, Washington. 
WHC-EP-0365-1

APPENDIX A

A. 0-1 
WHC-EP-0365-1

This page intentionally left blank.

A. 0-2 


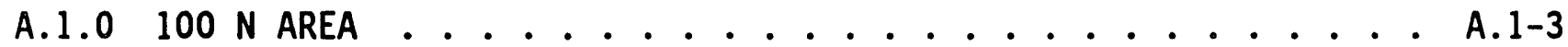

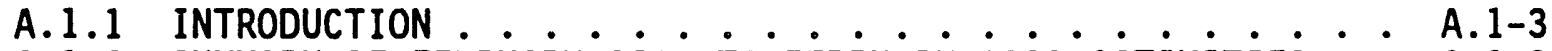

A.1.2 SUMMARY OF FEBRUARY 1990 TO FEBRUARY 1991 ACTIVITIES * A.1-3

A.1.3 STATUS OF 1991 ACTIVITIES IN PROGRESS ....... A.1-3

A.1.4 CURRENT INVENTORY AND/OR AMOUNTS GENERATED ....... A.1-3

A.1.5 WASTE MINIMIZATION ACTIVITIES ......... A.1-4

A.1.6 ESTIMATE OF PLANNED WORK ACTIVITIES FOR $1992 \ldots \ldots$. . . A.1-4

A.2.0 CURRENT WASTE GENERATORS IN THE 300 AREA . . . . . . A.2-1

A.2.1 DESCRIPTION OF FACILITIES AND TYPES OF WASTES

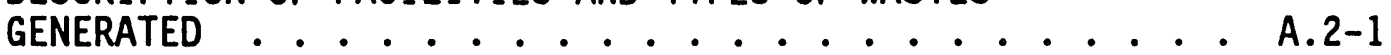

A.2.1.1 324 Chemical Engineering Laboratory . . . . A.2-1

A.2.1.2 325 Radiochemistry Laboratory . . . . . . . A.2-2

A.2.1.3 326 Materials Technology Laboratory . . . . A.2-3

A.2.1.4 327 Postirradiation Testing Laboratory .... A.2-3

A.2.1.5 329 Physics Science Laboratory . . . . . . A.2-4

A.2.1.6 3720 Building . . . . . . . . . A.2-4

A.2.1.7 331 Life Sciences Laboratory ... . . . A.2-5

A.2.1.8 340 Waste Handling Facility . . . . . . A.2-5

A.3.0 CURRENT WASTE GENERATORS AT THE 400 AREA . . . . . . . . A.3-1

A.3.1 DESCRIPTION OF FACILITY AND TYPES OF WASTE GENERATED * - A.3-1

A.3.2 GENERATION OF TANK WASTES IN THE 400 AREA ..... A.3-1

A.3.3 TANK WASTE MINIMIZATION AT THE FAST FLUX TEST FACILITY AND AT THE MAINTENANCE AND STORAGE FACILITY ... . A.3-2

A.3.4 FUTURE TANK WASTE GENERATED AS A RESULT OF THE FAST FLUX TEST FACILITY SHUTDOWN OPTION . . . . . . . A.3-2

A.4.0 TANK FARMS ....................... . . . . .

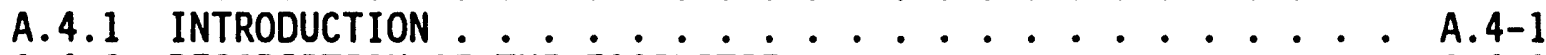

A.4.2 DESCRIPTION OF THE FACILITIES ........... A.4-1

A.4.2.1 Single-Shell Tanks .......... A.4-1

A.4.2.2 Double-She11 Tanks . . A.4-1

A.4.3 ADDITIONS TO THE DOUBLE-SHELL TANKS FROM TANK FARM

A.4.4 WASTE MINIMIZATION ACTIVITIES ................. A.4

A.5.0 EVAPORATORS ................ A.5-1

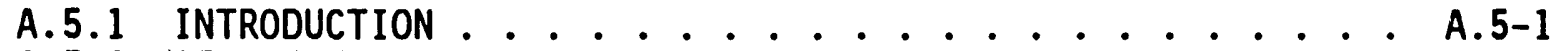

A.5.2 DESCRIPTION OF EVAPORATOR FACILITIES ....... A.5-1

A.5.3 TYPES OF WASTE GENERATED ............ A.5-1

A.5.4 STATUS OF ACTIVITIES IN PROGRESS ......... A.5-2

A.5.5 WASTE MINIMIZATION .............. A.5-2

A.5.6 PLANNED WORK ..................... A. . .

A.6.0 PLUTONIUM FINISHING PLANT . . . . . . . . . . . A.6-1

A.6.1 INTRODUCTION . . . . . . . . A.6-1

A.6.2 RECAP OF FEBRUARY 1990 TO FEBRUARY 1991 ACTIVITIES . A.6-1

A.6.2.1 Planned Treatment of Plutonium Finishing

Plant Waste............... A.6-1 
WHC-EP-0365-1

\section{CONTENTS (continued)}

\section{A.6.2.2 Hanford Private Sector Participation} Conference ............. A.6-1

A.6.2.3 Plutonium Reclamation Facility Process Modification ............ A.6-1

A.6.3 WASTE GENERATED AND CURRENT INVENTORY . . . . . . . A.6-2

A.6.4 WASTE MINIMIZATION ACTIVITIES . . . . . . . . . . . . A.6-2

A.6.4.1 Remote Mechanical "C" Line Process Changes . A.6-2

A.6.4.2 Plutonium Reclamation Facility Process

A.6.4.3 Plutonium Finishing Plant Waste Minimization * A.6-2

A.7.0 PUREX PLANT . . . . . . . . . . . . . . . . . A.7-1

A.7.1 INTRODUCTION .................. A.7-1

A.7.2 DESCRIPTION .................. A.7-1

A.7.3 RECAP OF ACTIVITIES FROM FEBRUARY 1990 TO

FEBRUARY 1991 ................. A.2

A.7.3.1 Summary of Plant Operations--February 1990

to February 1991 . . . . . . . . . A.7-2

A.7.3.2 Waste Minimization Activities Initiated

Before February 1, 1990 . . . . . . . A.7-2

A.7.4 LISTING OF APPLICABLE DOCUMENTS . . . . . . . . . A.7-2

A.7.5 STATUS OF 1991 ACTIVITIES IN PROGRESS . . . . . . . . A.7-2

A.7.6 CURRENT INVENTORY AND AMOUNTS GENERATED ........ A.7-3

A.7.6.1 Tank Waste Inventory ............ A.7-3

A.7.6.2 Tank Waste Generated ... . . . . . . A.7-3

A.7.7 WASTE MINIMIZATION ACTIVITIES ........... A.7-3

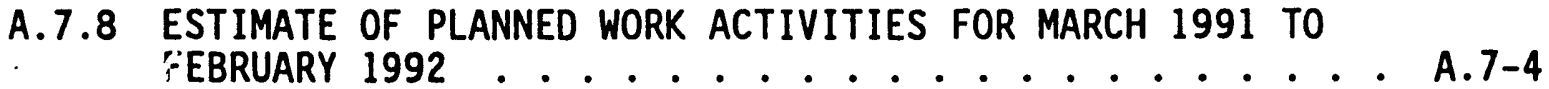

A.8.0 B PLANT . . . . . . . . . A.8-1

A.8.1 DESCRIPTION OF FACILITY ............. A.8-1

A.8.2 STATUS OF CURRENT ACTIVITIES . . . . . . . . . . . A.8-1

A.8.2.1 Support to the Waste Encapsulation and Storage Facility for Storage of Cesium and Strontium Capsules ............ A.8-1

A.8.2.2 Management of an Existing Inventory of Radioactive Liquid Waste .......... A.8-1

A.8.2.3 Management of an Existing Inventory of Radioactive Solid Waste.......... A.8-1

A.8.2.4 Treatment of Low-level Waste Generated by Operation of Essential Plant Ventilation Systems ................. A.8-2

A.8.2.5 Process Condensate Treatment Facility . . . . A.8-2

A.8.3 WASTE MINIMIZATION ACTIVITIES ............ A.8-2

A.8.3.1 Suspend Tank Farm Flushes .......... A.8-2

A.8.3.2 Minimize Tank Liquid Heel Replacement . . . . A.8-2

A.8.3.3 Rerouting of Waste and Elimination of Steam Jet Dilution ........... A.8-2

A.8.4 CURRENT INVENTORY AND/OR AMOUNTS GENERATED . . . . . . A.8-3

A.8.5 ESTIMATE OF PLANNED WORK ACTIVITIES . . . . . . . . . . A.8-3 


\section{CONTENTS (continued)}

A.9.0 222-S LABORATORY COMPLEX ... . . . . . . . . . . . . A.9-1

A.9.1 DESCRIPTION OF LABORATORY-COMPLEX FUNCTION, FACILITIES, AND WASTE .................. A.9-1

A.9.1.1 Laboratory-Complex Function . . . . . . . A.9-1

A.9.1.2 Facilities ............... A.9-1

A.9.1.3 Waste................. A.9-2

A.9.2 WASTE MINIMIZATION . . . . . . . . . . . . A.9-5

A.10.0 T PLANT . . . . . . . . . . . . . . . . . A.10-1

A.10.1 FACILITY DESCRIPTION . . . . . . . . . . . A.10-1

A.10.2 SUMMARY OF MARCH 1990 TO FEBRUARY 1991 ACTIVITIES

AND WASTE GENERATED . . . . . . . . . . . . A.10-1

A.10.3 STATUS OF ACTIVITIES IN PROGRESS ......... . A.10-2

A.10.4 CURRENT INVENTORY AND/OR AMOUNTS GENERATED . . . . . . A.10-2

A.10.5 WASTE MINIMIZATION ACTIVITIES . . . . . . . . . A.10-2

A.10.6 ESTIMATE OF PLANNED WORK ACTIVITIES FOR 1992 . . . . A.10-2

A.11.0 HANFORD WASTE VITRIFICATION PLANT . . . . . . . . . . . . A.11-1

A.12.0 GROUT TREATMENT FACILITY . . . . . . . . . . . . . . . . . A.12-1

A.12.1 DESCRIPTION OF FACILITY AND TYPES OF WASTE

GENERATED . . . . . . . . . . . . . . . . . A.12-1

A.12.1.1 Description of Facility . . . . . . . A.12-1

A.12.1.2 Type of Waste Generated . . . . . . . . A.12-1

A.12.2 WASTE MINIMIZATION ACTIVITIES . . . . . . . . . . . . A.12-1

A.12.2.1 Employee Training . . . . . . . . . . A.12-2

A.12.2.2 Employee Participation and Incentive

Program . . . . . . . . . . . A.12-2

A.12.2.3 New Projects and Designs . . . . . . A.12-2 
WHC-EP-0365-1

\section{LIST OF FIGURES}

A.9-1 Concentration of 222-S Laboratory Waste . . . . . . . . A.9-4

\section{LIST OF TABLES}

A.4-1 Chronology of the Double-Shell Tank Construction . . . . . A.4-2

A.9-1 . 222-S Laboratory Waste Composition . . . . . . . . . . . . . . A.9-3 


\section{LIST OF TERMS}

$\begin{array}{ll}\text { ALC } & \text { airlift circulator } \\ \text { CAW } & \text { current acid waste } \\ \text { D\&D } & \text { decontamination and decommissioning } \\ \text { DOE } & \text { U.S. Department of Energy } \\ \text { DMF } & \text { Dry Materials Facility } \\ \text { DST } & \text { double-shell tank } \\ \text { Ecology } & \text { Washington State Department of Ecology } \\ \text { FFTF } & \text { Fast Flux Test Facility } \\ \text { FY } & \text { fiscal year } \\ \text { GDF } & \text { Grouted Waste Disposal Facility } \\ \text { GPF } & \text { Grout Processing Facility } \\ \text { GTF } & \text { Grout Treatment Facility } \\ \text { HWWP } & \text { Hanford Waste Vitrification Plant } \\ \text { IEM } & \text { Interim Examination and Maintenance (Cell) } \\ \text { LLW } & \text { low-level waste } \\ \text { MASF } & \text { Maintenance and Storage Facility } \\ \text { NCAW } & \text { neutralized current acid waste } \\ \text { NCRW } & \text { neutralized cladding removal waste } \\ \text { NZAW } & \text { neutralized zirflex acid waste } \\ \text { OA } & \text { outside air } \\ \text { PFP } & \text { Plutonium Finishing Plant } \\ \text { PUREX } & \text { Plutonium/Uranium Extraction (Plant) } \\ \text { SST } & \text { single-shell tank } \\ \text { SWL } & \text { saltwell liquor } \\ \text { TRU } & \text { transuranic (waste) } \\ \text { TRUEX } & \text { transuranium extraction } \\ \text { UGS } & \text { underground storage } \\ \text { WAC } & \text { Washington Administrative Code } \\ \text { WESF } & \text { Waste Encapsulation and Storage Facility } \\ \text { WIPP } & \text { Waste Isolation Pilot Plant } \\ & \end{array}$


WHC-EP-0365-1

This page intentionally left blank.

A. 0-8 
WHC-EP-0365-1

APPENDIX A.1

A. 1-1 
WHC-EP-0365-1

This page intentionally left blank.

A. 1-2 


\section{A.1.0 100 N AREA}

This section documents the studies, activities, and issues which occurred in this area over the period of March 1, 1990, through February 28, 1991.

\section{A.1.1 INTRODUCTION}

The principal facility in the $100 \mathrm{~N}$ Area is the dual-purpose $\mathrm{N}$ Reactor, which was designed to produce special nuclear materials and steam for generating electricity. Support facilities for $N$ Reactor include a waterfilled fuel storage basin and decontamination systems for both the reactor and fuel storage basin.

The three primary types of waste generated at this facility during operation are $\mathrm{N}$ reactor decontamination waste, ion-exchange regeneration waste, and sand filter backwash.

Because of the standby status of the $N$ Reactor, no new waste from reactor operations was generated from February 1990 to February 1991.

\section{A.1.2 SUMMARY OF FEBRUARY 1990 TO FEBRUARY 1991 ACTIVITIES}

This section traces the processing of the remaining waste stored in the fuel storage basin. Normally, this remaining waste would be processed through the ion-exchange system, which would generate an estimated $36,000 \mathrm{gal}$ of waste. The generation of this waste will not take place for two reasons: (1) there is limited 200 Area tank space and (2) the need for ion-exchange column use and regeneration has been eliminated because of a reduction of storage basin water radionuclide concentrations experienced since the completion of irradiated-fuel transfers to the K Basins in December 1989.

\section{A.1.3 STATUS OF 1991 ACTIVITIES IN PROGRESS}

A sand filter is used to remove entrained solids from the fuel storage basin water before treatment with ion exchange during normal operations. The sand filter backwash is primarily an inorganic sludgo generated during periodic filter flushing to remove accumulated solids. Currently, the sand filters at $107-\mathrm{N}$ are operating on day shift only to maintain the proper water $\mathrm{pH}$ and visibility.

\section{A.1.4 CURRENT INVENTORY AND/OR AMOUNTS GENERATED}

The regeneration waste tank in $107-\mathrm{N}$ is currently holding $20,000 \mathrm{gal}$ of sulfate waste that is projected to be shipped to the tank farms in fiscal year (FY) 1992. 


\section{A.1.5 WASTE MINIMIZATION ACTIVITIES}

No new waste minimization activities are in place.

\section{A.1.6 ESTIMATE OF PLANNED WORK ACTIVITIES FOR 1992}

The following activities are planned for 1992:

- Fifteen thousand gallons of liquid wash-down waste is expected from tank cleanout and layup activities.

- The operation of the sand filters mentioned in Section 2.5 necessitates backwashes that add to the sludge volume in the backwash settling tank. The sludge hold-up volume is estimated to be 1,000 gal. This sulfate waste also is projected to be shipped in 1992 but will require additional liquid for dilution because of the fissile content and high dose rate experienced because of the concentration of radionuclides present in the constituent. Total estimated dilution gallons are 90,000.

- N Reactor is anticipating a FY 1991 Shutdown Order and that direction has been received. The wastes to be generated will be dependent upon scope and schedule of shutdown activities. 
WHC-EP-0365-1

\section{A.2.0 CURRENT WASTE GENERATORS IN THE 300 AREA}

This section documents the studies, activities, and issues which occurred in this area over the period of March 1, 1990, through February 28, 1991.

\section{A.2.1 DESCRIPTION OF FACILITIES AND TYPES OF WASTES GENERATED}

In the 300 Area, tank waste is generated in seven different laboratory facilities and transferred to the 340 Waste Handling Facility for shipment to the tank farms for storage, any necessary treatment, and ultimate disposal. Since the report of 1990, the program to manage and dispose of 1 iquid wastes in the 300 Area has been greatly enhanced. Generators must fill out a request form for disposal to the Radioactive Liquid Waste System (RLWS) which lists the waste description, radionuclides, hazardous constituents, gallons of waste, and other information. This information is then entered into a database that tracks waste volumes transferred to the 340 facility.

Descriptions of the seven individual laboratory facilities, the 340 facility, and their individual waste streams are presented in this chapter. A composite analysis of the tank waste generated in the 300 Area is included in the discussion of the 340 facility.

\section{A.2.1.1 324 Chemical Engineering Laboratory}

The 324 Chemical Engineering Laboratory contribution to tank waste is principally from two groups of shielded hot cells and their service and operating galleries. Liquid wastes that are produced during the operation of these hot cell facilities are pumped from vault tanks through the RLWS 1 ine to the 340 facility for temporary storage before transfer by rail tank car to the tank farms. In some cases, wastes are delivered to the 340 facility in steel drums.

The waste generated by the operation of the 324 laboratory hot cells is generally water that has been contaminated with radioactive materials as a result of being used to clean and rinse contaminated equipment. Other wastes generated in the facility include condensates from research activities. A description of the amount and type of waste that is produced in the 324 Laboratory in a typical year follows:

- Volume--7,800 gal/yr

- Chemical composition--Water

- Predominant radionuclides--Cesium-137 ( $\left.{ }^{137} \mathrm{Cs}\right)$ and strontium-90 $\left({ }^{90} \mathrm{Sr}\right)$ with mixed fission products (MFP) and mixed activation products (MAP). 
The reason for the large increase in liquid waste disposed of by this facility compared to last year is due to the disposal of former product materials that were being stored in three tanks (102, 103, and 108). In addition, a large amount of condensate was generated and disposed of during 1990.

\section{A.2.1.2 325 Radiochemistry Laboratory}

The 325 Radiochemistry Laboratory is a multipurpose laboratory facility with two different sets of hot cells and many analytical laboratories. Waste volumes have been reduced in each laboratory area of the 325 Building complex. This can be attributed to waste minimization efforts as well as the temporary cessation of SST/DST core characterization activities caused by funding and waste disposal concerns.

The hot cells located in the east wing of the 325A Building are used to handle highly radioactive materials for a variety of processes and tests. The inorganic waste produced in the cells generally consists of rinse water and dissolved irradiated fuel sample sections. The waste generated in the $325 \mathrm{~A}$ Building drains to a less-than-90-d storage tank in that facility and is jetted to the RLWS 1 ine to the 340 facility. The research hot cells are used to extrude and blend core samples from the tank farms. A description of the waste that will be generated in the process research hot cells is as follows:

- Volume--1,700 gal/yr

- Chemical composition--Inorganic acid

- Predominant radionuclides--Cerium-144 $\left({ }^{144} \mathrm{Ce}\right)$, cobalt-60 $\left({ }_{106}^{60} \mathrm{Co}\right)$, cesium-134 $\left({ }^{134} \mathrm{Cs}\right)$, cesium-137 $\left({ }^{137} \mathrm{Cs}\right)$, and ruthenium-106 ( $\left.{ }^{106} \mathrm{Ru}\right)$ with MFP and MAP.

The hot cells in the 325B Building are used to dissolve fuel components and other solids in acid before chemical analysis. The waste that is generated in these hot cells is primarily rinse water and is only slightiy radioactive. These hot cells drain to a less-than-90-day tank connected to the RLWS 1 ine and the 340 facility. A description of the waste generated in the 325B Building cells follows:

- Volume--5 gal/yr

- Chemical composition--Water

- Predominant radionuclides--Cerium-144 $\left({ }^{144} \mathrm{Ce}\right)$, cobalt-60 $\left({ }^{60} \mathrm{Co}\right)$, cesium-134 $\left({ }^{134} \mathrm{Cs}\right)$, cesium-137 $\left({ }^{137} \mathrm{Cs}\right)$, and ruthenium-106 ( $\left.{ }^{106} \mathrm{Ru}\right)$ with MFP and MAP. 
The analytical laboratory waste generated in the 325 Building is sent directly to the 340 facility via the RLWS drains. Most of the waste is generated from fuel rod analysis. A general description of the waste produced from laboratory analytical work follows:

- Volume--14 gal/yr

- Chemical composition--Inorganic analytical waste

- Predominant radionuclides--Cerium-144 $\left({ }^{144} \mathrm{Ce}\right)$, cobalt-60 $\left({ }^{60} \mathrm{Co}\right)$, cesium-134 $\left({ }^{134} \mathrm{Cs}\right)$, cesium-137 $\left({ }^{137} \mathrm{Cs}\right)$, and ruthenium-106 $\left({ }^{106} \mathrm{Ru}\right)$ with MFP and MAP.

\section{A.2.1.3 326 Materials Technology Laboratory}

Most of the work performed in the 326 Materials Technology Laboratory involves the study of metallurgical, chemical, and physical behavior of reactor components and fuel materials. In mid 1990, the RLWS system in the 326 Building was administratively closed and remains unused. Only 1 gal of 326 Building waste was sent to the 340 facility during the year. It is unlikely that any waste from this building will be sent to the 340 facility next year. Most of the waste generated in this building was shipped to the Central Waste Complex in steel drums for storage as Radioactive Mixed Waste (RMW). This was performed because the waste did not meet the 340 Facility acceptance criteria. Any waste generated in the future that meets the 340 Facility acceptance criteria will be disposed of to the 340 Facility via the RLWS line in the 329 Building.

The metallography laboratory, where radioactive waste is generated, is used to prepare metal coupons for survey in an electron microscope. The coupons are prepared by washing them in several different acids baths. A general description of the waste that was generated in this section of the 326 Building in 1990 is as follows:

- Volume--1 gal/yr

- Chemical composition--Dilute perchloric and acetic acids and isobutyl alcohol

- Predominant radionuclides--radioactive metals.

\section{A.2.1.4 327 Postirradiation Testing Laboratory}

The 327 Postirradiation Testing Laboratory is used for destructive and nondestructive examination of irradiated reactor fuel and structural materials. These examinations and the associated testing are carried out in 12 shielded cells, several of which drain to the 340 Building via the RLWS. The cell drains are filtered to prevent solids from entering the RLWS piping and 340 facility tanks. Most of the waste is generated during grinding and 
cutting operations, performed on irradiated fuels and materials, and when the equipment in the cells is cleaned and rinsed. A general description of the waste that is generated by the 327 laboratory follows:

- Volume--400 gal/yr

- Chemical composition--Water mixed with decontamination materials

- Predominant radionuclides--Cerium-144 $\left({ }^{144} \mathrm{Ce}\right)$, cesium-137 $\left({ }^{137} \mathrm{Cs}\right)$, and strontium-90 ( $\left.{ }^{90} \mathrm{Sr}\right)$.

The reduction in 7 iquid waste disposed of to the 340 facility compared to last year $(10,000 \mathrm{gal})$ is due to two reasons. The data given in the report of last year was an estimate. Second, 327 laboratory personnel have applied waste minimization techniques to reduce the amount of water used to clean the cells.

\section{A.2.1.5 329 Physics Science Laboratory}

The 329 Physics Science Laboratory includes laboratories for radioanalysis and low-level detection and measurement of radioisotopes. Radioactive sources are also manufactured in this laboratory.

The experiments or processes used in the radiochemical portion of the 329 laboratory include dissolution of solids, ion-exchange and precipitation partitioning, and liquid extractions. A description of the waste typically generated in the radiochemistry portion of the 329 laboratory follows:

- Volume--332 gal/yr

- Chemical composition--Nitrate, carbonate, oxalate, sulfate, fluorine, sodium, and ammonia

- Predominant radionuclides-Americium-241 ( $\left.{ }^{241} \mathrm{Am}\right)$, cobalt-60 $\left({ }^{60} \mathrm{Co}\right)$, cesium $\left({ }^{137} \mathrm{Cs}\right)$, iron-55 ( $\left.{ }^{55} \mathrm{Fe}\right)$, niobium-93m ( $\left.{ }^{93} \mathrm{mNb}\right)$, nickel-63 ( $\left.{ }^{63} \mathrm{Ni}\right)$, plutonium-239 ( $\left.{ }^{239} \mathrm{Pu}\right)$, plutonium-240 ( $\left.{ }^{240} \mathrm{Pu}\right)$, and strontium-90 ( $\left.{ }^{90} \mathrm{Sr}\right)$.

Only a small amount of waste is produced in the low-level detection

facility. A general description of the waste produced follows:

- Volume--1 gal/yr

- Chemical composition--Water

- Predominant radionuclides--Cobalt-60 $\left({ }^{60} \mathrm{Co}\right)$, cesium-137 $\left({ }^{137} \mathrm{Cs}\right)$, and strontium-90 ( $\left.{ }^{90} \mathrm{Sr}\right)$.

\section{A.2.1.6 3720 Building}

Several laboratories are housed in the 3720 Building. Of these only the Geochemistry group currently generates radioactive waste as a result of the study of radioactive grouts and their leachates. The small amount of radio 
active waste generated in the 3720 Building is collected in drums and transported to the 340 facility where it is added to the accumulation tanks. A general description of the waste being generated follows:

- Volume--200 gal/yr

- Chemical composition--Varies depending on experiment

- Predominant radionuclides--Iodine-125 ( $\left.{ }^{125} \mathrm{I}\right)$ and technetium-99 $\left({ }^{99} \mathrm{Tc}\right)$.

One other project currently being conducted in the 3720 Building that generates tank wastes is the result of field lysimeter studies. A general description of the lysimeter waste that will be generated from lysimeter studies follows:

- Volume--100 gal/yr decreasing by $25 \% / \mathrm{yr}$

- Chemical composition--Varies depending on experiment

- Predominant radionuclides--At or below detection levels.

\section{A.2.1.7 331 Life Sciences Laboratory}

The 331 Life Sciences Laboratory is used for a variety of biological and ecological research studies. No waste generated at the 331 Building was sent to the 340 facility in 1990. The wastes are either packaged into steel drums and sent to Central Waste Complex for storage as RMW or absorbed and disposed of as low-level radioactive waste (nonhazardous liquids).

\section{A.2.1.8 340 Waste Handling Facility}

A.2.1.8.1 Description. The 340 facility is a liquid waste handling facility. Waste is received from PNL via underground pipelines into the 340 storage tanks. The 340 facility transfers the waste into 20,000-gal railcars and ships them to the DSTs via the 204AR unloading facility. As part of operating the facility, some quantities of liquid waste are generated.

\section{A.2.1.8.2 Summary of February 1990 to February 1991. Following a railcar} loading operation, waste transfer 1 ines are flushed to reduce contamination and radiation levels. Each transfer generates approximately 50 gal of waste. In the past year, the 340 facility has made 8 transfers adding $400 \mathrm{gal}$ to the tank waste inventory.

Periodic decontamination activities (i.e., sampling hood, floor sump, equipment repairs) have resulted in some waste generation. For the past year it is estimated approximately $500 \mathrm{gal}$ of waste was added to the tank waste inventory.

In December of 1990 , severe temperatures froze several water lines in contaminated areas of the 340 facility. The frozen lines burst, adding approximately 1,200 gal to the tank waste inventory. 
A.2.1.8.3 Listing of Applicable Documents. Occurrence Report Number WHC-90-0372-340 (water 1 ine rupture).

A.2.1.8.4 Status of 1991 Activities in Progress. Decontamination of the 340 complex is under way. The facility is attempting to reduce contamination to levels within the required action limits. Since February, approximately 2,000 gal of waste have been generated. This effort is neariy complete.

A.2.1.8.5 Waste Minimization Activities. In the past, the 340 facility would flush both the fill and the vent transfer lines after each railcar loading. The radiation levels and contamination levels in the vent line are not measurably increased during a transfer. The railcar loading procedure was revised to require a vent line flush only when directed by supervision. Until the levels in the vent line become of concern, the line will not be flushed. This has reduced the amount of flush generated at the facility by $50 \%$.

A.2.1.8.6 Estimate of Planned Work Activities for 1992. The six 340A storage tanks are to be flushed of residual solids. It is anticipated that this effort will generate 8,000 to 10,000 gal of waste. 
WHC-EP-0365-1

\section{A.3.0 CURRENT WASTE GENERATORS AT THE 400 AREA}

This section documents the studies, activities, and issues which occurred in this area over the period of March 1, 1990, through February 28, 1991.

\section{A.3.1 DESCRIPTION OF FACILITY AND TYPES OF WASTE GENERATED}

The 400 Area contains the Fast Flux Test Facility (FFTF), a U.S. Government-owned nuclear reactor specifically designed for the irradiation and testing of nuclear reactor fuels and materials. The FFTF plays a key role in developing and testing fuels and materials for application in fast neutron flux reactors and in testing fusion reactor materials.

This 400-MW fast-breeder reactor is located in a shielded cell in the center of the containment building. The heat generated by the fission process is removed from the reactor by liquid sodium circulating under low pressure through three primary coolant loops. An intermediate heat exchanger in each of these three loops separates the radioactive sodium in the primary system from the nonradioactive sodium in the secondary system. The radioactive primary sodium does not leave the Reactor Containment Building. Three secondary sodium loops transport reactor heat from the intermediate heat exchangers to the air-cooled tubes of the 12 dump-heat exchangers.

The FFTF also includes facilities for receiving, conditioning, storing, and installing core components and test assc hlies. Examination and packaging capabilities for onsite and offsite shipments and radioactive waste handling are provided.

\section{A.3.2 GENERATION OF TANK WASTES IN THE 400 AREA}

In the 400 Area, radioactive liquid wastes are generated primarily in conjunction with the removal of residual sodium from irradiated reactor components and fuel assemblies in the Interim Examination and Maintenance (IEM) Cell and by the cleaning and decontamination activities conducted in the Maintenance and Storage Facility (MASF). Wastewater, which is generated during the cleaning processes, is stored in a 5,000-gal-capacity tank at the FFTF and in two 5,000-gal-capacity tanks at the MASF. The wasiewater is moved from the FFTF to the MASF via an 8,000-gal-capacity railcar and then transferred to the 200 Area Tank Farms via a 20,000-gal-capacity rail tank car. A shipment of the contaminated wastewater to the 200 Area Tank Farms occurs approximately once every $2 \mathrm{yr}$.

During the past year, 2,600 gal of wastewater was generated in the IEM Cell and 540 gal was generated in the MASF. This volume is currently stored in the 8,000-gal railcar at MASF. These amounts are consistent with the generation rate over the last several years. 


\section{A.3.3 TANK WASTE MINIMIZATION AT THE FAST FLUX TEST FACILITY AND AT THE MAINTENANCE AND STORAGE FACILITY}

The design of the cleaning systems used in the IEM Cell enables the washwater to be recirculated to the greatest extent possible, which minimizes the amount of radioactive tank waste generated by the facility. Current practices generate about 500 gal of contaminated water with each cleaning episode. The total quantity of wastewater generated each year in the IEM Cell is dependent on the number of reactor assemblies washed.

An annual hydrologic test is required for the 8,000-gal-capacity tank car which is used to ship waste from the FFTF to the MASF. The testing method includes filling the tank with water. After the test is complete, the water used in the test is shipped to the 200 Area Tani Farms. The amount of washwater generated annually by the IEM Cell and the MASF is less than what is required to perform the test. To further minimize the amount of tank waste generated in the 400 Area, procedures have been changed to allow the use of existing wastewater from the two 5,000-gal-capacity tanks at the MASF to help fill the tank car for the required annual hydrologic test. This results in a substantial reduction in the volume of wastewater generated annually.

\section{A.3.4 FUTURE TANK WASTE GENERATED AS A RESULT OF THE FAST FLUX TEST FACILITY SHUTDOWN OPTION}

The future of the FFTF and the MASF is undetermined at this time. If the reactor is to begin permanent shutdown, the amount of wastewater generated would vary greatiy depending upon the method selected for sodium disposal. The possibility exists that up to 500,000 gal of radioactive $50 \%$ sodium hydroxide solution would be generated by reacting the sodium, which would be drained from the FFTF. This solution will need to be treated as radioactive waste. In addition, 250,000 gal of slightly contaminated and low-level radioactive water or alcohol could be generated as a result of sodium removal operations in the FFTF piping and components after the bulk sodium is drained. 


\section{A.4.0 TANK FARMS}

This section documents the studies, activities, and issues which occurred in this area over the period of March 1, 1990, through February 28, 1991.

\section{A.4.1 INTRODUCTION}

The tank farms located in the 200 East and 200 West areas of the Hanford Site were built for storing and managing radioactive wastes generated by various production and laboratory operations. The tanks are of two different types--single-shell tanks (SST) and double-shell tanks (DST).

\section{A.4.2 DESCRIPTION OF THE FACILITIES}

\section{A.4.2.1 Single-Shell Tanks}

Between 1943 and 1964, 149 SSTs were built for storing radioactive wastes. These SSTs are located in 12 tank farms, with each tank farm consisting of 4 to 18 SSTS.

The SSTs have volumes of 55,000 to $1,000,000 \mathrm{gal}$. One hundred thirtythree of the SSTs are $75 \mathrm{ft}$ in diameter and 29.75 to $54 \mathrm{ft}$ high, with nominal capacities of 500,000 to $1,000,000$ gal. Sixteen of the SSTs are smaller units of similar design--20 ft in diameter and $25.5 \mathrm{ft}$ high with capacities of 55,000 gal each.

The tanks are located below grade with at least $6 \mathrm{ft}$ of soil covering the tanks to provide shielding and minimize the radiation exposure to tank farm operating personnel. Most of the 500,000- and 750,000-gal-capacity SSTs were built in the form of "cascades" of three or four SSTs each. Waste was transferred to the first SST in the cascade and allowed to overflow into each of the successive SSTs in the cascade through inlet and overflow lines located near the top of the steel liner within in each SST.

Access to each of the SSTs is provided by risers penetrating the domed top of the SSTS. These risers vary in diameter from 4 to 42 in. Each of the SSTs have up to 11 risers, with the majority of the SSTs having 3 to 5 risers.

Radioactive waste generated during the various Hanford Site operations was not placed into SSTs after November 1980. While the SSTs are considered to have been "taken out of service" in November 1980, the 149 tanks continue to hold approximately 37 Mgal of saltcake, sludge, and interstitial liquid.

\section{A.4.2.2 Double-She11 Tanks}

Between 1968 and 1986, 28 DSTs were constructed: 3 of these tanks are located in the 200 West Area (241-SY Tank Farm) and an additional 25 tanks are located in the 200 East Area (241-AN, -AP, -AW, -AY, and -AZ Tank Farms). All 
of these DSTs were constructed at least $5 \mathrm{ft}$ below grade to provide shielding and minimize the radiation exposures of operating personnel. Table A.4-1 provides a chronology of the DST construction.

The four 241-AY and $-A Z$ tanks each have a 1-Mgal capacity and are designed to store the high-heat-generating neutralized current acid waste (NCAW) from the Plutonium-Uranium Extraction (PUREX) process. These tanks are referred to as aging waste tanks and have airlift circulators for mixing and a vessel ventilation system designed to remove and condense steam.

Table A.4-1. Chronology of the Double-Shell Tank Construction.

\begin{tabular}{|c|c|c|c|c|}
\hline Tank farm & $\begin{array}{c}\text { Year } \\
\text { constructed }\end{array}$ & $\begin{array}{c}\text { No. of } \\
\text { tanks }\end{array}$ & $\begin{array}{c}\text { Tank volume } \\
\text { (Mgal) }\end{array}$ & Comment \\
\hline $241-$ AY & $1968-70$ & 2 & 1.00 & Aging waste tank \\
\hline $241-\mathrm{AZ}$ & $1971-77$ & 2 & 1.00 & Aging waste tank \\
\hline $241-\mathrm{SY}$ & $1974-76$ & 3 & 1.14 & - \\
\hline $241-\mathrm{AW}$ & $1978-80$ & 6 & 1.14 & - \\
\hline $241-\mathrm{AN}$ & $1980-81$ & 7 & 1.14 & - \\
\hline $241-\mathrm{AP}$ & $1983-86$ & 8 & 1.14 & - \\
\hline
\end{tabular}

The DSTs use a tank-within-a-tank design to provide double containment of the radioactive liquid and solid wastes. This design ensures that if a leak in the primary shell occurs, the liquid waste will be fully contained by the outer shell.

The freestanding primary tank is about $75 \mathrm{ft}$ in diameter and $46 \mathrm{ft}$ high at the dome crown. The carbon steel in the bottom of the tank ranges from 0.5 to 1 in. thick. The primary tank wall thickness ranges from $1 / 2$ to $3 / 4$ in. with the dome thickness at $3 / 8$ in.

An annular space of $2.5 \mathrm{ft}$ is provided between the primary tank and the secondary steel tank that allows room for installation of liquid-level and leak detection devices; inspection equipment, such as periscopes, television cameras, and photographic cameras; ventilation air supply and exhaust ducts; and equipment for pumping liquid out of the annular space.

Tank dome penetrations in the primary tank and annulus allow for various monitoring and processing activities. Primary tank monitoring activities include measurement of liquid level, sludge level, temperature, and pressure. 


\section{A.4.3 ADDITIONS TO THE DOUBLE-SHELL TANKS FROM TANK FARM OPERATION (FEBRUARY 1990 TO FEBRUARY 1991)}

The tank farm facilities at the Hanford Site receive radioactive wastes generated by other Hanford Site waste generators. Tank farm operations are typically characterized as a waste receiver rather than a waste generator. However, in the operation of the tank farms, a variety of additions are made that increase the volume of the wastes in the tanks. These streams are identified because their minimization has the overall effect of reducing the volume requiring treatment for final disposal. The additions of waste from these streams are addressed for the period February 1990 to February 1991.

1. Saltwell Liquor--The SSTs hold moist solids (salts and sludges) that contain interstitial liquid. Saltwell pumping can remove a portion of the interstitial liquid called saltwell liquor (SWL) from these solids. Through calendar year 1990, 105 SSTs have been interim stabilized, leaving 44 SSTs to be interim stabilized by the end of FY 1995 (Tri-Party Agreement Milestone M-05).

During the February 1990 to February 1991 time frame, 35,500 gal of pump able liquid was removed from the SSTs and transferred to DSTs. It is predicted that $4,000,000 \mathrm{gal}$ will be removed from the SSTs by FY 1995 when the saltwell pumping program is expected to be completed.

2. Airlift Circulator (ALC) Flushes--Salts are periodically flushed from the ALCs in the aging waste double-shell tanks using raw water. The volume of ALC water flushes for the specified time period was $6,050 \mathrm{gal}$.

3. Aging Waste Ventilation System De-entrainer Flushes--This activity, necessary to keep the de-entrainers from plugging, added 6,100 gal of de-entrainer flush water to the aging waste tanks.

4. Jet Pump Transfers--Waste transferred from catch tanks to DSTs using a jet pump added 18,115 gal of motive water to the DSTs.

5. The DST 241-AZ-101 Aging Waste Steam Condensate--The DST 241-AZ-101 contains steam coils to boil water from the aging waste. To prevent these steam coils from freezing during winter weather, a small amount of steam must be allowed through the coils. This produced an estimated $2,500 \mathrm{gal}$ of condensate that was directed to the aging waste tanks.

6. Tank Car Waste Flushing and Water from Recertification--Radioactive waste is shipped by rail tank car to the 200 East Area DSTs from the $100-N, 300$, and 400 areas. The tank car used to transport this waste must be flushed and recertified. The volume of waste generated during these operations was $71,850 \mathrm{gal}$. 
7. Flush and Wash--Water is used to periodically wash accumulated solids and salts from measurement equipment. Other equipment inust be flushed after use or for maintenance. Equipment wash and flush water added 9,000 gal to the DSTs. Line flushes after tank to tank transfers accounted for 9,765 gal of water added to the DSTs.

8. Evaporator Drainage--Water was added to the DSTs from both the 242-A and 242-S Evaporators during the time period. The water comes mostly from flushing and washing for maintenance activities. The total addition from the evaporators was $10,050 \mathrm{gal}$.

Two streams identified in last year's report as estimated additions to the tanks are not reported in this account. The caustic addition to DST 241-AN-107, identified last year as item number 4, was not carried out as expected. This action is still under study and will be reported in a future report if it is implemented.

Item number 5 of 1 ast year's report is the steam condensate from Tank Farm 241-SY ventilation system. A check on the configuration of the ventilation system showed that this stream is not added to the DSTs. The condensate from the vapors in the ventilation system does return to the DSTs, but it does not constitute an addition of new waste. This stream will no longer be addressed.

It is anticipated that volume additions to the DSTs in 1991 will be in the same range as the results reported in this section.

\section{A.4.4 WASTE MINIMIZATION ACTIVITIES}

Forecasts that current rates of waste generation will fill the DSTs in 1991 have prompted a Hanford Site-wide effort to significantly reduce the amount of waste sent to the DSTs. Within the tank farm operating area the following waste-avoiding activities were adopted in the 1990 time frame.

1. The frequency of the Ventilation S,stem 702-A de-entrainer flush has been reduced, avoiding $30,000 \mathrm{gal}$ of water being sent to the aging waste tank. In conjunction with this, water used in the jet transfer of flush water from the 152-AX Catch Tank to the aging waste tanks will be reduced by $28,000 \mathrm{gal}$.

2. Tank Farm 241-AZ air-1ift circulator flush was reduced by $50 \%$, thus avoiding 55,000 gal of waste generation.

3. The flushing of the 241-AY Tank Farm air-1ift circulators was discontinued for six months. This saved 9,000 gal of water from going to the aging waste tanks.

4. Several miscellaneous streams have been eliminated, thus avoiding the generation of an estimated 50,000 gal of waste. 


\section{A.5.0 EVAPORATORS}

This section documents the studies, activities, and issues which occurred in this area over the period of March 1, 1990, through February 28, 1991.

\section{A.5.1 INTRODUCTION}

Since the early 1950s, eight evaporator facilities have been used to treat tank wastes at the Hanford Site. The only evaporator facility that is planned for continued operation is the 242-A Evaporator-Crystallizer located in the 200 East Area. The schedule for the 242-A Evaporator-Crystallizer was to remain shuidown during March 1990 to February 1991.

\section{A.5.2 DESCRIPTION OF EVAPORATOR FACILITIES}

The evaporator building is divided into rooms housing particular process components or support facilities. The main process rooms are the evaporator room contains the reboiler and vapor-liquid separator, the condenser room houses the overhead vapor condensers and condensate collection tank, and the slurry pumps are in the pump room. Support "ooms include the control room; loading room; heating, ventilation, and air conditioning (HVAC) room; and change rooms.

The 242-A Evaporator is used to reduce the volume of radioactive mixed waste requiring storage in the DSTs. The evaporator uses forced circulation through the reboiler and vapor-liquid separator to heat the waste under vacuum causing vaporization of water and other volatiles. The vapors from the separator are condensed, retained, and then treated prior to disposal. The slurry product stream is sent back to the DSTs from the evaporator. The vo? ume of the slurry-product stream is significantly less than the volume of the waste feed stream.

\section{A.5.3 TYPES OF WASTE GENERATED}

The operation of the Evaporator-Crystallizer 242-A does not generate new tank waste except when there is a process upset. The following streams are generated:

- DSSF, which is returned to DSTs

- Steam condensate from reboiler, which is sent to the 216-B-3 Pond

- Process condensate, which is held for treatment

- Cooling water from the process condenser, which is sent to the 216-B-3 Pond

- Smal1-volume, intermittent wastes such as de-entrainer wash, which are sent to the evaporator pot. 
The slurry returned to the DSTs was originally a DST waste before being pumped into the evaporator, so it is not considered an original waste stream for the tank farms.

The smal1-volume, intermittent wastes such as de-entrainer wash, are sent to the evaporator pot where their identity is lost during evaporation with DSSF.

If there is an upset condition and process condensate becomes contaminated with radionuclides, the process condensate may be returned to a DST. Upset conditions seldom occur and the process condensate is typically not considered a tank waste.

\section{A.5.4 STATUS OF ACTIVITIES IN PROGRESS}

Previously, process condensate was discharged untreated to the Hanford Site soil column in the 200 East Area because it was not typically considered a tank waste. This practice has been discortinued and a new collection, treatment, and processing facility is being constructed to treat process condensate.

\section{A.5.5 WASTE MINIMIZATION}

An equipment modification was made to eliminate the only active waste stream when the evaporator is not operating. This involved replacing the existing air sample vacuum pump which required a constant seal water stream with a pump that does not require seal water. This modification el iminates $90 \mathrm{gal} / \mathrm{h}$ or $769,000 \mathrm{gal} / \mathrm{yr}$ of discharge from the evaporator.

\section{A.5.6 PLANNED WORK}

Evaporator-Crystallizer 242-A will resume operation after improvements and additions are completed in 1991. Operation of the evaporator will reduce the volume of liquids currently stored in DSTs. 


\section{A.6.0 PLUTONIUM FINISHING PLANT}

This section documents the studies, activities, and issues which occurred in this area over the period of March 1, 1990, through February 28, 1991.

\section{A.6.1 INTRODUCTION}

The Plutonium Finishing Plant (PFP) is located in the 200 West Area of the Hanford Site. The PFP has the primary mission of plutonium processing, handling, and storage. Stabilization of plutonium scrap to plutonium oxide, waste treatment, product storage, and packaging for shipment are the principal operations conducted at the PFP. Plutonium metal will not be produced at the PFP because of changes in the defense production mission at the Hanford Site.

\section{A.6.2 RECAP OF FEBRUARY 1990 TO FEBRUARY 1991 ACTIVITIES}

\section{A.6.2.1 Planned Treatment of Plutonium Finishing Plant Waste}

The transuranium extraction (TRUEX) process will not be used for the removal and recovery of plutonium and americium fractions from the PFP process waste solutions to produce a low-level waste (LLW) as explained in the 1990 report. Present plans are to develop and utilize a PFP Waste Sol idification Process (Project $\mathrm{C}-130$ ) where the process waste will be treated for the removal of organics, nitrates, and water and then solidified. The resultant solids will either contain transuranic waste (TRU) or low-level amounts of TRU which will be solidified into 55-gal drums and certified as Waste Isolation Pilot Plant (WIPP) waste for final emplacement at the WIPP site in Carlsbad, New Mexico, or for burial at the Hanford Low-Level Burial site. Project C-130 is planned as an FY 1995 Line Item, which means the design for the PFP Waste Solidification Process is scheduled to start in FY 1995.

\section{A.6.2.2 Hanford Private Sector Participation Conference}

There were no proposals received from the private sector for development and design of processes for conversion of 1 iquid to solid waste as described in the 1990 report. Westinghouse Hanford Company is pursuing the PFP Waste Solidification Process, Project $\mathrm{C}-130$, which is now the planned treatment for PFP 1 iquid TRU wastes. Project $\mathrm{C}-130$ is described above in Section 6.2.1.

\section{A.6.2.3 Plutonium Reclamation Facility Process Modification}

Bypassing of the $O A$ Column during plutonium-only and uranium depletion solvent extraction operations, as described in the 1990 report, will take place when the Plutonium Reclamation Facility starts up. 


\section{A.6.3 WASTE GENERATED AND CURRENT INVENTORY}

Approximately 13,160 gal of ?iquid wastes were generated in calendar year 1990. Fifty-three hundred $\mathrm{kg}$ of treatment chemicals ( 780 gal of solution) were also added to the waste tanks. Approximately 13,600 gal in treated waste were transferred to the 224-TX intermediate storage tank for transfer to DST 241-SY-10, and finally to the 200 East Area tank storage. There were 2,700 gal of waste remaining in PFP waste tanks on December $31,1990$.

\section{A.6.4 WASTE MINIMIZATION ACTIVITIES}

\section{A.6.4.1 Remote Mechanical "C" Line Process Changes}

Plutonium metal will not be produced at the PFP because of changes in the defense production mission at the Hanford Site. The following wastes will, therefore, not be generated at the PFP:

- Possibie accidental emissions of hydrogen fluoride gas into the atmosphere

- Calcium waste generated during the plutonium fluoride reduction step. This calcium comes from spillage and excess amounts added

- Slag and crucible waste generated during plutonium metal casting

- Aqueous $50 \%$ potassium hydroxide $(\mathrm{KOH})$ scrubber waste generated from the hydrofluoric (HF) scrubber system

- Routine TRU solid glovebox waste generated during plutonium metal production.

\section{A.6.4.2 Plutonium Reclamation Facility Process Modification}

In addition to the modifications described in the 1990 report, the following modifications for abatement of $\mathrm{CCl}_{4}$ emissions are being investigated.

- Placement of a "water cap" between the $\mathrm{CCl}_{4}$ and the air pulser on pulse extraction columns to minimize the emission of $\mathrm{CCl}_{4}$. The extraction columns are known to be a major source of $\mathrm{CCl}_{4}$ emissions.

- Replacement of present "air bubbler dip tube" liquid-level measuring devices with electronic level measuring devices. The present measurement technique bubbles air through the $\mathrm{CCl}_{4}$ solutions and increases the volume of vapors generated. 
- Use of a silicone fluid in a scrubber system to absorb $\mathrm{CCl}_{4}$ vapors and prevent them from entering the atmosphere. The $\mathrm{CCl}_{4}$ can be released from the silicone fluid at elevated temperatures and perhaps be recycled in the process, thus minimizing the volume required in a processing campaign.

- Investigations are being conducted to find a replacement solvent for $\mathrm{CCl}_{4}$ which is more environmentally acceptable.

\section{A.6.4.3 Plutonium Finishing Plant Waste Minimization}

Waste minimization activities described in the 1990 report are continuing. The following activities are in addition to those described.

- Redundant and more dependable liquid-level measuring devices are being designed for the liquid waste intermediate storage tanks in Building 241-Z.

- Systems and processes draining to the intermediate storage tanks in Building 241-Z were checked to eliminate all water leaks. Systems presentiy not in use had the water to them shut off to prevent any accidental releases.

- Temperature- or flow-measuring devices will be designed and installed on drain lines leading to Building $241-Z$ to ensure that any accidental leaks or discharges will be detected as early as possible.

- Waste analysis plan to characterize the chemical composition of the different process streams was developed and will be used whenever one of the processes is placed into operation.

- A PFP staff member has developed a "Pollution Prevention" presentation and is presenting it to all personnel stationed at the PFP. At the end of each presentation, participation of those attending is solicited and any suggestions/ideas concerning pollution prevention/waste minimization are discussed. These ideas are being tabulated and will be evaluated by the PFP Waste Minimization Team for applicability to PFP or the Hanford Site. 
WHC-EP-0365-1

This page intentionally left blank.

A. 6-4 


\section{A.7.0 PUREX PLANT}

This section documents the studies, activities, and issues which occurred in this area over the period of March 1, 1990, through February 28, 1991.

\section{A.7.1 INTRODUCTION}

The PUREX plant processes irradiated nuclear reactor fuels for the recovery of uranium and plutonium. During the February 1, 1990, to February 1, 1991, time frame, the PUREX facility completed a Stabilization Run. At the completion of this activity in March 1990, the facility entered into an extended plant outage and then was directed to be placed in cold standby pending a decision on future fuel processing. The changes in the type of plant operations (i.e., fuel processing to cold standby) have resulted in a need to reevaluate previous plans for reducing tank wastes and to develop new plans.

\section{A.7.2 DESCRIPTION}

Tank wastes produced fall into four general types: neutralized current acid waste (NCAW), neutralized cladding removal waste (NCRW), miscellaneous wastes, and solvent recovery wastes. The NCAW is the aqueous high-salt waste from the first-cycle solvent extraction column in the PUREX process. The NCRW results from the dissolution of the $N$ Reactor spent-fuel Zircalloy cladding using the Zirflex process in the PUREX plant. The miscellaneous wastes come from various sources throughout the plant. The solvent recovery wastes result from washing and regenerating the nonregulated organic solvent (tributyl phosphate/ normal paraffin hydrocarbon) used in the PUREX solvent extraction systems.

The NCAW, NCRW, and the miscellaneous waste are all radioactive mixed waste regulated by the U.S. Department of Energy (DOE) and the Washington State Department of Ecology (Ecology). The solvent recovery wastes are radioactive waste regulated by DOE only. The $\mathrm{pH}$ of all wastes is adjusted to greater than 12 and sodium nitrate is added for corrosion control before transfer to underground storage (UGS) in the DSTs. The DSTs are managed by the Tank Farms organization.

During the Stabilization Run, NCAW, NCRW, miscellaneous waste, and solvent recovery wastes were produced. During cold standby, the main type of waste being generated is miscellaneous waste. A small amount of solvent recovery waste may also be produced. The NCAW and NCRW will not be generated during cold standby. Total volume of waste generated during cold standby will be less than when the plant is operating. 
WHC-EP-0365-1

\section{A.7.3 RECAP OF ACTIVITIES FROM FEBRUARY 1990 TO FEBRUARY 1991}

\section{A.7.3.1 Summary of Plant Ope-ations--February 1990 to February 1991}

February to March 1990: Dewing this period, PUREX was comp ing the Stabilization Run (December 1989 to March 1990). The Stabilization Run was used to stabilize the facility by processing the material remaining in the system after the December 1988 shutdown and cleaning out the equipment for an extended maintenance outage.

March 1990 to February 1991: In March 1990, the ollant was shut down for an extended maintenance outage to correct operational and safety concerns. In October 1990 DOE directed that the PUREX facility transition to and be maintained in a cold standby condition. Cold standby involves placing the plant into a safe and environmentally sound condition that does not compromise future fuel processing. Cold standby is to be maintained until an

Environmental Impact Statement is completed and a Record of Decision is 1 ssued on the disposition of the remaining irradiated fuel at the Hanford Site.

\section{A.7.3.2 Waste Minimization Activities Initiated Before February 1, 1990}

Among the many waste minimization initiatives at the PUREX Facility, the only activity whose status changed during the March 1990 to February 1991 time frame is as follows.

Work on the ammonia destruction system for the ammonia generated during fuel decladding has been suspended because the plant was placed in cold standby. Resumption of work will depend on a decision to restart the facility and upon the possible elimination of the Zirflex fuel dissolution process by the shear/leach fuel dissolution process.

\section{A.7.4 LISTING OF APPLICABLE DOCUMENTS}

No studies on tank waste minimization were published between February 1 , 1990, and February 1, 1991.

\section{A.7.5 STATUS OF 1991 ACTIVITIES IN PROGRESS}

Steam condensate is generated from the tank heaters for the UNH product tanks in the 203-A Area.

To reduce the amount of steam condensate entering the miscellaneous waste stream, the heaters are turned off during the warm weather of summer, spring, and fall. 
Since completion of the Stabilization Run, some steam lines have been shut down to reduce the amount of steam condensate entering the miscellaneous tank waste stream. This is a continuing effort. Additional steam lines are being examined to determine if they can be shut down.

\section{A.7.6 CURRENT INVENTORY AND AMOUNTS GENERATED}

\section{A.7.6.1 Tank Waste Inventory}

None of the tanks used to collect tank waste which are generated at the PUREX facility are permitted for long-term storage of these wastes. The tanks used to gather the NCAW, NCRW, and miscellaneous waste are permitted as 90-d accumulation tanks and do not store tank waste. The solvent recovery tanks contain radioactive nonregulated waste and do not meet the criteria for permitting. As a matter of operating practice, solvent recovery wastes are also transferred to Tank Farms within $90 \mathrm{~d}$.

\section{A.7.6.2 Tank Waste Generated}

Between February 1, 1990, and February 1, 1991, the following types and amounts of tank wastes were transferred from the PUREX facility to the Tank Farms DSTs:

$\begin{array}{lr}\text { NZAW waste: } & 143.6 \mathrm{~m}^{3} \\ \text { NCRW waste: } & 85.5 \mathrm{~m}^{3} \\ \text { Miscellaneous waste: } & 1641.4 \mathrm{~m}^{3} \\ \text { Solvent Recovery waste: } & 378.3 \mathrm{~m}^{3}\end{array}$

\section{A.7.7 WASTE MINIMIZATION ACTIVITIES}

During the Stabilization Run (December 1989 to March 1990), the miscellaneous tank waste was minimized by reducing chemical flows during startup, operating chemical flows in the minimum optimal amounts during the run, and by shipping off-specification plutonium nitrate to PFP to take advantage of the more efficient PFP rework process.

The shutdown of the PUREX facility at the completion of the Stabilization Run has reduced or eliminated some of the sources of tank waste generated. In general, sources directly related to processing operations have been eliminated, while sources required to support and maintain the equipment have been reduced.

Water is being reused for the waste tank flushing, calibrations, and integrity assessments instead of using fresh water for each of these steps. This practice has reduced the volume of tank waste. Both the solvent recovery and miscellaneous tank wastes stream were minimized. 


\section{A.7.8 ESTIMATE OF PLANNED WORK ACTIVITIES \\ FOR MARCH 1991 TO FEBRUARY 1992}

The major expected efforts involving tank waste are the process waste assessments. These assessments will be used to meet the new Ecology requirements for waste minimization plans in the Washington Administrative Code (WAC) 173-306. Final details and schedule have not yet been established. 
WHC-EP-0365-1

\section{A.8.0 B PLANT}

This section documents the studies, activities, and issues which occurred in this area over the period of March 1, 1990, through February 28, 1991.

\section{A.8.1 DESCRIPTION OF FACILITY}

$B$ Plant is designed to remotely process radioactive materials with no radiation exposure to operators. The first mission of $B$ Plant was to reprocess spent fuel between 1945 and 1952 using the bismuth phosphate process.

B Plant was refurbished for Mission 2 (1965 to 1985) to recover and purify cesium and strontium from newly generated current acid waste (CAW) and from stored wastes in tanks (NCAW). The facility is now being refurbished for Mission 3 to pretreat tank wastes before vitrification in the Hanford Waste Vitrification Plant (HWVP). However, a program redefinition investigation preliminary report concludes B Plant will not be used for pretreatment. The final report will be issued to Ecology in January 1992.

\section{A.8.2 STATUS OF CURRENT ACTIVITIES}

\section{A.8.2.1 Support to the Waste Encapsulation and Storage Facility for Storage of Cesium and Strontium Capsules}

B Plant currently provides demineralized water to Waste Encapsulation and Storage Facility (WESF) for pool-cell storage of cesium and strontium capsules. B Plant also provides treatment for low-level radioactive liquid waste produced at WESF, as well as lag storage for radioactive solid waste generated at WESF.

\section{A.8.2.2 Management of an Existing Inventory of Radioactive Liquid Waste}

Radioactive liquid waste is currently in storage at B Plant. This waste includes organic solutions containing cesium and strontium as weil as some organic solvents. These liquid wastes are at B Plant as a result of previous missions. Several tanks at B Plant currently contain NCAW waste, which was transferred to B Plant for the purpose of waste pretreatment studies.

\section{A.8.2.3 Management of an Existing Inventory of Radioactive Solid Waste}

B Plant currently stores drums of radioactive solid waste in Cell 4. These drums of waste, as well as some waste piles stored on the canyon deck (used jumpers and miscellaneous piping), are the result of both past and current operations at B Plant and WESF. 


\section{A.8.2.4 Treatment of Low-level Waste Generated by Operation of Essential Plant Ventilation Systems}

Low-level radioactive liquid wastes generated at $B$ Plant and WESF as process condensate are neutralized before transfer to the DST.

\section{A.8.2.5 Process Condensate Treatment Facility}

A study is currently under way to evaluate the options for treatment of process condensate which is generated by the operation of the B Plant concentrator.

\section{A.8.3 WASTE MINIMIZATION ACTIVITIES}

Several waste minimization activities have been initiated at B Plant. The following items are directly related to DST waste minimization.

\section{A.8.3.1 Suspend Tank Farm Flushes}

Past practice at B Plant was to flush the transfer line to Tank Farms after each waste transfer to flush solids from the transfer line. This resulted in supplemental waste in the amount of 3,750 gal for each flush being sent to the DST. Transfer line flushing is required if the solids content of the waste is greater than $4 \%$. Flushing was performed before receipt of any solids testing results. The current practice is to suspend flushing before solids content reporting and to perform flushing only when solids content has been shown to be above $4 \%$. This practice, implemented in March 1990, has provided a total of 205,000 gal of waste minimization in the time period of interest (March 1, 1990, to February 28, 1991).

\section{A.8.3.2 Minimize Tank Liquid Heel Replacement}

Tank liquid heels, also known as water seals, have been maintained with demineralized water according to past practice at $B$ Plant. These water seals are used to prevent contamination between tanks which are connected to a common ventilation system. This practice was discontinued in June 1990 and maintenance of heels is now accomplished with low-level radioactive liquid in lieu of sending it to DST. Waste minimization of 43,000 gal was realized during this 12-mo reporting period.

\section{A.8.3.3 Rerouting of Waste and Elimination of Steam Jet Dilution}

By rerouting the low-level waste through tanks equipped with water pumps (24-1 to 25-1 vs. 24-1 to 23-3 to 23-1 to 25-1) rather than steam jets, the need for steam jetting was eliminated which, in turn, eliminated a source of dilution. Waste minimization of approximately 25,000 gal was realized during this 12-mo reporting period. 


\section{A.8.4 CURRENT INVENTORY AND/OR AMOUNTS GENERATED}

During the time period between March 1, 1990, and February 28, 1991 , $B$ Plant transferred 411,000 gal of low-level radioactive waste to the DST. This waste is primarily process condensate which is generated by operation of essential plant ventilation systems.

\section{A.8.5 ESTIMATE OF PLANNED WORK ACTIVITIES}

The following two activities are planned to prepare for future missions.

- Preparation for TRUEX pilot plant will be initiated by flushing and cleanout of existing process equipment.

- Operation of the low-level waste concentrator will provide system optimization and characterization of the B Plant process condensate and B Plant steam condensate effluent streams. 
WHC-EP-0365-1

This page intentionally left blank.

Â. 8-4 
WHC-EP-0365-1

\section{A.9.0 222-S LABORATORY COMPLEX}

This section documents the studies, activities, and issues which occurred in this area over the period of March 1, 1990, through February 28, 1991.

\section{A.9.1 DESCRIPTION OF LABORATORY-COMPLEX FUNCTION, FACILITIES, AND WASTE}

\section{A.9.1.1 Laboratory-Complex Function}

The 222-S Laboratory Complex (222-S Complex), in the southeast corner of the 200 West Area, consists of the 222-S Laboratory (222-S), the 222-SA Standards Laboratory, and several ancillary facilities. The main facility of the complex consists of the 222-S Laboratory, which provides analytical chemistry and radiological services in support of Westinghouse Hanford Company (Westinghouse Hanford).

The main role lately for 222-S is to support efforts to characterize the waste stored in the 200 Areas SSTs. Besides this work, the laboratory also provides analytical services for waste-management processing plants, Tank Farms, B Plant, 242-A Evaporator Facility, PIJREX Plant, PFP, UO $\mathrm{U}_{3}$ Plant, WESF, environmental monitoring and surveillance programs, and activities involving essential materials and research and development. At this time, the 222-S facilities, equipment, and procedures are being upgraded to support Resource Conservation and Recovery Act (RCRA) analytical protocols and programs for environmental restoration and DST characterization.

\section{A.9.1.2 Facilities}

The 222-S Laboratory is housed in a two-story, aboveground building, $322 \mathrm{ft}$ long and $107 \mathrm{ft}$ wide. This structure is divided into laboratory support spaces, office, spaces, a multi-curie wing, and supplemental service areas. It has facilities for waste disposal and decontamination, and systems for ventilation, radiation monitoring, and fire protection, including alarms.

The first floor of 222-S is divided into three general sections: west, east, and central. The west section contains a lunchroom, offices, and changerooms; this section is kept free of radioactivity and toxic chemicals. The central section has service areas and laboratories where toxic chemicals and low-level radioactive materials are analyzed; intermediate-level radioactive samples are also analyzed, occasionally. The east section, commonly known as the multi-curie section, has laboratories and cells in which intermediate-level radioactive materials are analyzed. It also has service areas.

The 219-S Waste Handling Facility (219-S) has three storage tanks in which liquid acid waste from 222-S can be received, stored temporarily, and neutralized. From this facility, neutralized waste, which may contain radionuclides, is transferred to the Tank Farms. A sodium-hydroxide supply tank, 700-gal capacity, is also located in this facility. 
The 207-SL Retention Basin (207-SL) is used for temporarily storing potentially radioactive or hazardous liquid effluent from 222-S Laboratory. Samples of the wastewater, free of contamination normally, are analyzed and the results compared against surface-discharge specifications for alpha and beta activity, nitrate, total organic carbon, and $\mathrm{pH}$. Should the wastewater be in compliance with the specifications, it is discharged to the 216-S-26 Crib (216-5-26). However, should the wastewater be out of compliance, it is routed to the underground storage tanks of the 219-S Waste Handling Facility. From 219-S, this wastewater will be transferred to the Tank Farms for storage in Tank 204-AR. Transferring of the waste currently is by way of truck-hauled tankers. A piping system directly to the Tank Farms does exist, but has been removed from service; the system will be either repaired and upgraded or replaced with a new one.

The 216-S-26 Crib receives all wastewater collected in 207-SL that meets radiological and chemical specifications. It is designed to handle $75,000 \mathrm{gal} / \mathrm{d}$ or $25,000 \mathrm{gal} / 8 \mathrm{-h}$ shift. The crib currently receives about $7,000 \mathrm{gal} / \mathrm{d}$ during summer months and 15,000 gal/d during winter months. Operation and control of this crib is the responsibility of Tank Farm Operations.

The 222-SA Standards Laboratory provides procedures and chemical standards for analyses performed at 222-S Laboratory.

\section{A.9.1.3 Waste}

Most waste generated at the 222-S Complex derives from analytical activities in 222-S. Waste acid from 222-S is pumped to 219-S. There are three tanks in 219-S (TK-101, TK-102, and TK-103) that receive hazardous and radioactive liquid waste. Waste acid solution from $222-5$ is pumped to either TK-101 or TK-103. From these tanks, the waste is transferred to TK-102 for pH neutralizing using sodium hydroxide. As needed, sodium nitrite is added to the solution, which raises its ritrite concentration to levels meeting tank farm specifications. Then to ensure adequate mixing of the waste constituents, the solution is agitated. After these steps are completed, the neutralized acid waste is ready for transfer to the Tank Farms for long-term storage until it can be disposed of permanently.

The types and respective concentrations of wastes typically resulting from laboratory activities are shown in Table A.9-1. Figure A.9-1 illustrates typical concentrations of 222-S waste. The volumes of waste generated, chemical compositions, radionuclide constituents and concentrations, and amounts of solids may vary depending on the analytical activities in use supporting the needs of different programs.

Intermediate-level radioactive waste streams are pumped to tank 101 of 219-S. These streams originate from hood drains, Decontamination Hood No. 16, hot laboratory sinks, and inductively coupled plasma analyzers.

High-level radioactive waste streams are pumped to Tank-103 and originate from hot cell drains, slurping done at Decontamination Hood No. 16, the 1-F Manipulator-Repair Hood drain, the atomic-absorption spectrophotometer hood drain, and hot tunnel sumps. 
Table A.9-1. 222-S Laboratory Waste Composition.

\begin{tabular}{|c|c|}
\hline Chemical & Composition \\
\hline \multicolumn{2}{|c|}{ Liquids } \\
\hline Carbonate & 5.0 E-03 M \\
\hline Total organic carbon & $1.0 \mathrm{E}+00 \mathrm{~g} / \mathrm{L}$ \\
\hline Fluoride & $1.0 \mathrm{E}-03 \mathrm{M}$ \\
\hline Nitrite & $2.5 E-02 \mathrm{M}$ \\
\hline Nitrate & $1.0 \mathrm{E}-01 \mathrm{M}$ \\
\hline Phosphate & $5.0 \mathrm{E}-03 \underline{\mathrm{M}}$ \\
\hline Sulfate & $2.0 \mathrm{E}-02 \mathrm{M}$ \\
\hline Sodium & $2.5 \mathrm{E}-01 \underline{M}$ \\
\hline Hydroxide & $1.0 \mathrm{E}-01 \mathrm{M}$ \\
\hline \multicolumn{2}{|c|}{ Radionuclides } \\
\hline Total alpha & $5.0 \mathrm{E}-06 \mathrm{Ci} / \mathrm{L}$ \\
\hline Total beta & $2.0 \mathrm{E}-04 \mathrm{Ci} / \mathrm{L}$ \\
\hline${ }^{137} \mathrm{Cs}$ & $5.0 \mathrm{E}-05 \mathrm{Ci} / \mathrm{L}$ \\
\hline${ }^{89,90} \mathrm{Sr}$ & $3.0 \mathrm{E}-05 \mathrm{ci} / \mathrm{L}$ \\
\hline Plutonium & $4.0 \mathrm{E}-05 \mathrm{~g} / \mathrm{L}$ \\
\hline Uranium & $1.0 \mathrm{E}-02 \mathrm{~g} / \mathrm{L}$ \\
\hline \multicolumn{2}{|c|}{ Solids } \\
\hline Percent & $0.00 E+0$ \\
\hline
\end{tabular}


Figure A.9-1. Concentration of 222-S Laboratory Waste.

\begin{tabular}{|c|c|c|c|c|}
\hline \multicolumn{5}{|c|}{$\begin{array}{c}\text { Condensate } \\
\text { Volume } 0.980 \mathrm{gal}\end{array}$} \\
\hline \multicolumn{2}{|c|}{ REDOX Complex Waste } & $!$ & \multicolumn{2}{|c|}{ DSSF } \\
\hline $\begin{array}{l}\mathrm{NaOH} \\
\mathrm{NaNO}_{2}\end{array}$ & $\begin{array}{l}0.10 \mathrm{M} \\
0.02 \mathrm{M}\end{array}$ & Evaporator & $\begin{array}{l}\mathrm{NaOH} \\
\mathrm{NaNO}_{2}\end{array}$ & $\begin{array}{l}3.78 \underline{M} \\
1.00\end{array}$ \\
\hline Volume & $1.0 \mathrm{gal}$ & & Volume & $0.02 \mathrm{gal}$ \\
\hline \multicolumn{5}{|c|}{$\begin{array}{l}\text { Condensate } \\
\text { Volume } 0.01 \text { gal }\end{array}$} \\
\hline \multicolumn{2}{|l|}{ DSS } & i & \multicolumn{2}{|c|}{ Supernatant } \\
\hline $\begin{array}{l}\mathrm{NaOH} \\
\mathrm{NaNO}_{2}\end{array}$ & $\begin{array}{l}8.00 \mathrm{M} \\
2.00 \mathrm{M}\end{array}$ & Evaporator & $\begin{array}{l}\mathrm{NaOH} \\
\mathrm{NaNO}_{2}\end{array}$ & $\begin{array}{l}4.00 \frac{M}{M} \\
1.00 \frac{M}{M}\end{array}$ \\
\hline Volume & $0.01 \mathrm{gal}$ & & Volume & $0.02 \mathrm{gal}$ \\
\hline
\end{tabular}




\section{A.9.2 WASTE MINIMIZATION}

Projected volumes of waste are based on facility operating plans, target waste-generation rates, and the SST- and DST-characterization schedules.

From FY 1991 through FY 1994, ten SST and DST core samples a year are scheduled for analysis. This schedule increases to 20 core samples a year from FY 1995 through FY 2015. These projections will be adjusted if schedules change. Also, extensive chemical and radionuclide analysis will continue through FY 1991, with subsequent projections based on the resulting analytical data.

Recent and continuing waste minimization actions reduce the waste sent to the 219-S Waste Handling Facility. Waste from this facility is transferred to Tank 204-AR. These actions are the following.

- Eliminating approximately 500 gal of flush water previously used for each waste transfer. This was accomplished by installing a flush line downstream of the waste tanks. Previously, after a waste tank was emptied, it was partially filled with clean water. The water rinsed the tank and then was pumped out through the transfer line, flushing it en route to a tanker. The new method improves on this by using far less water and providing flush water not containing waste residue from the tank.

- Reducing by $50 \%$ the volume of flush water used following the slurping of samples. It was determined that the additional volume previously used was not needed for adequate flushing.

Additional waste-minimization activities that may affect $219-5$ are being evaluated for possible implementation. An example is the development of an improved tracking system for managing the 222-S chemical inventory. Better control over this inventory should lead to reducing the amount of hazardous waste generated. Also, continuing training for operating personnel will further ensure that attention is focused on minimizing waste generation and preventing spills. 
WHC-EP-0365-1

This page intentionally left blank.

A. 9-6 


\section{A.10.0 T PLANT}

This section documents the studies, activities, and issues which occurred in this area over the period of March 1, 1990, through February 28, 1991.

\section{A.10.1 FACILITY DESCRIPTION}

$T$ Plant is located in the 200 West Area of the Hanford Site. The $T$ Plant's primary mission is equipment decontamination and refurbishment. The head end of the 221-T canyon building houses the Containment Systems Test Facility. This facility performs experimental testing which requires containment or isolation. The $T \mathrm{Pl}$ ant waste system handles radioactive liquid waste from decontamination activities in the hot cells, railroad tunnel, 2706-.T Building and the head end. The railroad tunnel generates waste from decontaminating railroad cars and multipurpose transfer boxes.

Most waste from cells in T Plant consists of water with settled solids generated during decontamination activities. Each cel1 in the 221-T Canyon has a 15-cm-dia. drain line that allows wastewater to drain into the canyon's 61-cm-dia. sewer line. Potentially contaminated wastes from the head end are al so drained through a $15-\mathrm{cm}$ line into the canyon's $61-\mathrm{cm}-\mathrm{dia}$. sewer 1 ine. This line empties into Tank 5-7 in the canyon. The waste in Tank 5-7 is transferred to Tank 15-1. In Tank 15-1, the waste is sampled, analyzed, then sent to 200 West Area Tank Farms via the cross-site transfer line or by certified railcar. If the waste is to be delivered via the cross-site transfer line, then the waste is chemically treated to meet Tank Farms' storage specifications before that transfer.

\section{A.10.2 SUMMARY OF MARCH 1990 TO FEBRUARY 1991 ACTIVITIES AND WASTE GENERATED}

During this time period, $T$ Plant was under limited operational status and generated only 19,866 gal of waste. This waste was transferred to Tank Farms. The composition of this waste is listed in Table A.10-1.

Table A.10-1. T Plant Tank Waste Characteristics.

\begin{tabular}{|l|l|}
\hline \multicolumn{1}{|c|}{ Analyte } & \multicolumn{1}{|c|}{ Results } \\
\hline Appearance & Light brown, no visible organic phase \\
\hline Total Solids & $<10 \%$ solids \\
\hline Total Alpha & $0.29 \mu \mathrm{Ci} / \mathrm{L}$ \\
\hline Total Beta & $12.6 \mu \mathrm{Ci} / \mathrm{L}$ \\
\hline pH & 12.03 \\
\hline
\end{tabular}




\section{A.10.3 STATUS OF ACTIVITIES IN PROGRESS}

$T$ Plant decontamination operations are currently in standby mode while planned facility upgrades are taking place and operating procedures are being updated and revised.

\section{A.10.4 CURRENT INVENTORY AND/OR AMOUNTS GENERATED}

Currently, almost all tank waste systems are empty. Until

decontamination operations are resumed, waste volumes produced will be limited.

\section{A.10.5 WASTE MINIMIZATION ACTIVITIES}

Product substitution has resulted in the elimination of methylene chloride, 1,1,1-trichloroethylene, and acetone-contaminated waste streams.

This year a manufacturer demonstration is scheduled onsite to provide $T$ Plant personnel a first-hand look at cleaning equipment that utilizes a high-velocity stream of dry-ice pellets to perform surface cleaning. This technology, if serviceable to $T$ Plant activities, could result in a substantial reduction in effluents from steam-cleaning operations on large, flat surfaces.

\section{A.10.6 ESTIMATE OF PLANNED WORK ACTIVITIES FOR 1992}

Because current decontamination operations are limited, the work load for 1992 is expected to be high. Ongoing D\&D activities and routine Site operations are creating an extensive backlog of equipment in need of decontamination. 
WHC-EP-0365-1

\section{A.11.0 HANFORD WASTE VITRIFICATION PLANT}

The HWVP will come on-line in 1999. The low-level waste generated at this facility will be returned to the DST farms for storage prior to grout disposal. 
WHC-EP-0365-1

This page intentionally left blank.

A. 11-2 
WHC-EP-0365-1

\section{A.12.0 GROUT TREATMENT FACILITY}

This section documents the studies, activities, and issues which occurred in this area over the period of March !, 1990, through February 28, 1991.

\section{A.12.1 DESCRIPTION OF FACILITY AND TYPES OF WASTE GENERATED}

\section{A.12.1.1 Description of Facility}

The Grout Treatment Facility (GTF), located in the 200 East Area of the Hanford Site, has the primary mission of permanently disposing of LLW. These LLWs will be blended with cementitious materials for immobilization and solidification in below-ground vaults. The GTF includes the Dry Materials Facility (DMF), the Grout Processing Facility (GPF), and the Grouted Waste Disposal Facility (GDF).

The DMF has the primary purpose of receiving, storing, and blending the dry cementitious grout materials. Materials used in this facility include portland cement, fly ash, and blast furnace slag. No radioactive materials are handled at the DMF.

The GPF has the main purpose of receiving radioactive liquid $L L W$ from the 241-AP Tank Farm feed tank, mixing it with the dry-blend materials from the DMF, and transferring the resulting grout mixture to a disposal vault.

The GDF is where the Grout Disposal Vaults are located. The grout slurry mixture is pumped into the vault and cures into a hardened grout product. Liquid waste generated by the grout process or excess water and leachate liquid from the vault during the setting and curing process is returned to the tank farms for processing. Flush liquids result in additional liquid waste.

\section{A.12.1.2 Type of Waste Generated}

The tank waste the GTF has generated is a low-activity radioactive and hazardous liquid waste (approximately $52,000 \mathrm{gal}$ in $2 \mathrm{yr}$ ).

\section{A.12.2 WASTE MINIMIZATION ACTIVITIES}

The waste minimization plan has the primary purpose to reduce the volume, weight, or toxicity of all regulated waste generated at the GTF to the extent practical. Areas addressed in the plan include organizational responsibilities, employee training, employee participation and incentive programs, and incorporation of waste minimization as part of the design process for new projects or designs. 


\section{A.12.2.1 Employee Training}

As part of general training for new employees, waste minimization training is included. General waste minimization training is provided to all employees of the GTF via waste minimization team awareness presentations and for hazardous waste shippers as part of the "Hazardous Waste Shipment Certification" class. Specific training and application of waste minimization techniques will be provided on an individual or group basis, as appropriate, by the respective manager or supervisor. The manager or supervisor is responsible for establishing employee responsibilities, assignments, and goals. Each group will keep a record of waste minimization training.

\section{A.12.2.2 Employee Participation and Incentive Program}

An employee participation and incentive program is part of the waste minimization plan at the GTF. Promotion and application of employee incentives appear to be a good way to minimize waste generation and maximize the use of good operating procedures. The incentive program has several compciients:

- Encourage employees to submit suggestions as Price proposals or Great Ideas

- Encourage employees to submit suggestions to the Westinghouse Hanford Company waste minimization specific incentive program (currently being developed)

- Encourage employees to submit "on-the-job" type waste minimization ideas directly to the GTF Waste Minimization Team with certificates and other "thanks" for this program.

\section{A.12.2.3 New Projects and Designs}

New projects and designs will be required to include waste minimization as an integral part of the design process. To accomplish this, the GTF waste minimization representative will review any proposed new construction and major grout process changes to ensure that waste minimization has been considered. New construction presently includes four Grout Disposal Vaults and modification to Tank 241-AP-104 for use as a second feed tank. New construction under consideration is a Grout Failed Equipment Handling Facility to stage contaminated failed equipment. 


\section{DISTRIBUTION}

Number of copies

OFFSITE

2

DOE Office of Civilian

Radioactive Waste Management

1000 Independence Avenue, S.W.

Washington, DC 20585

S. Gomberg

W. A. Stringfield

9

DOE Office of Operations

Trevion II Building

12800 iiddlebrook Rd.

Germantown, MD ¿0874

K. A. Chancey

S. P. Cowan

T. S. Gutmann

E. A. Jordan

J. Lytle

T. W. McIntosh

L. Smith

V. G. Trice

H. F. Walter

2

DOE Office of Environmental

Safety and Health

1000 Independence Avenue, S.W.

Washington, D.C. 20585

W. Fortune

T. Harms

3

DOE Idaho Operations Office

785 DOE Place

Idaho Falls, ID 83402

C. R. Enos

M. L. Shupe

J. E. Solecki

DOE Savannah River/DWPF Project Office

P.0. Box A

Aiken, SC 29801

K. Hall

W. D. Pearson

L. Watkins

Distr-1 
WHC-EP-0365-1

DISTRIBUTION (continued)

DOE West Valley Demonstration

Project

P.0. Box 191

West Valley, NY 14171

W. Bixby

E. Maestas

1

DOE Yucca Mountain Project Office

101 Convention Center Drive

Las Vegas, NV 89109

M. Cloninger

1

DOE Chicago/Materials

Integration office

9800 South Cass Avenue

Argonne, IL 60439

J. C. Haugen

3

Argonne National Laboratory 9700 South Cass Avenue Argonne, IL 60439

J. K. Bates

S. Vogler

R. Waiton

2

Lawrence Livermore National

Laboratory

P.0. Box 888

Livermore, CA 94550

L. Jardine

V. M. Oversby

7

Savannah River Laboratory

P.0. Box A

Aiken, SC 29801

R. G. Baxter

N. E. Bibler

M. D. Boersma

C. M. Jantzen

B. G. Kitchen

M. J. Plodinec

H. F. Teran 


\section{DISTRIBUTION (continued)}

\section{ONSITE}

U.S. Department of EnerqyRichland Operations Office

M. J. Anthony

A6-95

G. J. Bracken

A4-02

K. W. Bracken (4)

A5-22

R. W. Brown

A5-10

R. M. Carosino

A4-52

P. K. Clar":

A5-21

S. S. Clark

A6-55

M. Dev

R. E. Gerton

A5-21

R. D. Izatt

A4-02

P. E. LaMont

A5-19

B. L. Nicoll

A5-10

J. C. Peschong

A5-10

Public Reading Room

A5-21

A1-65

Pacific Northwest Laboratory

C. R. Allen

G6-06

W. F. Bonner

P7-44

J. L. Buelt

P7-44

H. C. Burkholder

P7-41

C. C. Chapman

P7-41

R. E. Einziger

P7-14

P. R. Hrma

K2-57

M. L. Knotek

$\mathrm{K} 1-48$

M. R. Kreiter

K6-35

A. Kruger

P8-37

W. W. Laity

L. T. Lakey

K2-15

D. E. Larson

K6-24

M. W. McCoy

G6-06

J. L. McElroy

P7-68

G. B. Mellinger

P7-46

J. E. Mendel

P7 -18

K. A. Parnell

P7-08

J. M. Perez

P7-18

M. E. Peterson

P7-41

W. A. Ross

P7-44

M. J. Schweiger

P7-41

P. A. Scott

K2-57

P. J. Turner

P7-44

P7-14 
WHC-EP-0365-1

DISTRIBUTION (continued)

ONSITE

West inghouse Hanford Company

S. A. Barker

R2-07

G. R. Bloom

L4-71

A. L. Boldt

H5-49

H. L. Debban (2)

J. L. Deichman (2)

$\mathrm{XO}-43$

T. A. Demitruk

$\mathrm{H} 4-23$

E. W. Gerber (2)

R3-09

D. L. Halgren

L5-62

W. H. Hamilton, Jr. (2)

R1-51

B. M. Hanlon

H. D. Harmon (2)

B. A. Higley

R. A. Karnesky

N3-10

$\mathrm{R} 1-80$

R2-52

M. J. Klem

H5- 49

J. A. Koerner

E. J. Kosiancic (2)

HO-39

R2-14

S6-60

M. J. Kupfer

S0-61

G. J. Lebaron

S. Marchetti

E. J. Mathos

J. C. Midgett

P. C. Miller

D. J. Newl and

R. J. Nicklas

J. V. Panesko

J. G. Propson

H5-49

S6-19

R2-50

T5-54

S6-15

N2-04

R2-28

R1-51

A4-90

J. A. Rawlins

R2-18

I. E. Reep

HO-36

L. D. Schwartz

H4-23

L6-40

R. A. Sexton

G6-08

D. J. Swaim (2)

N2-51

R. W. Szelmeczka

T3-28

J. J. Verderber

$51-57$

M. J. Vitulli

$\times 0-35$

E. C. Vogt (2)

T5-50

G. J. Warwick

T6-12

R. A. Watrous

G6-08

W. F. Zuroff

R2-14

EDMC

Central Files

$\mathrm{H} 4-22$

Correspondence Control

L8-04

Information Release

Administration

R1-03

Resource Assessment and

R1-08

Regulatory Integration

B2-35 


\section{$T$}
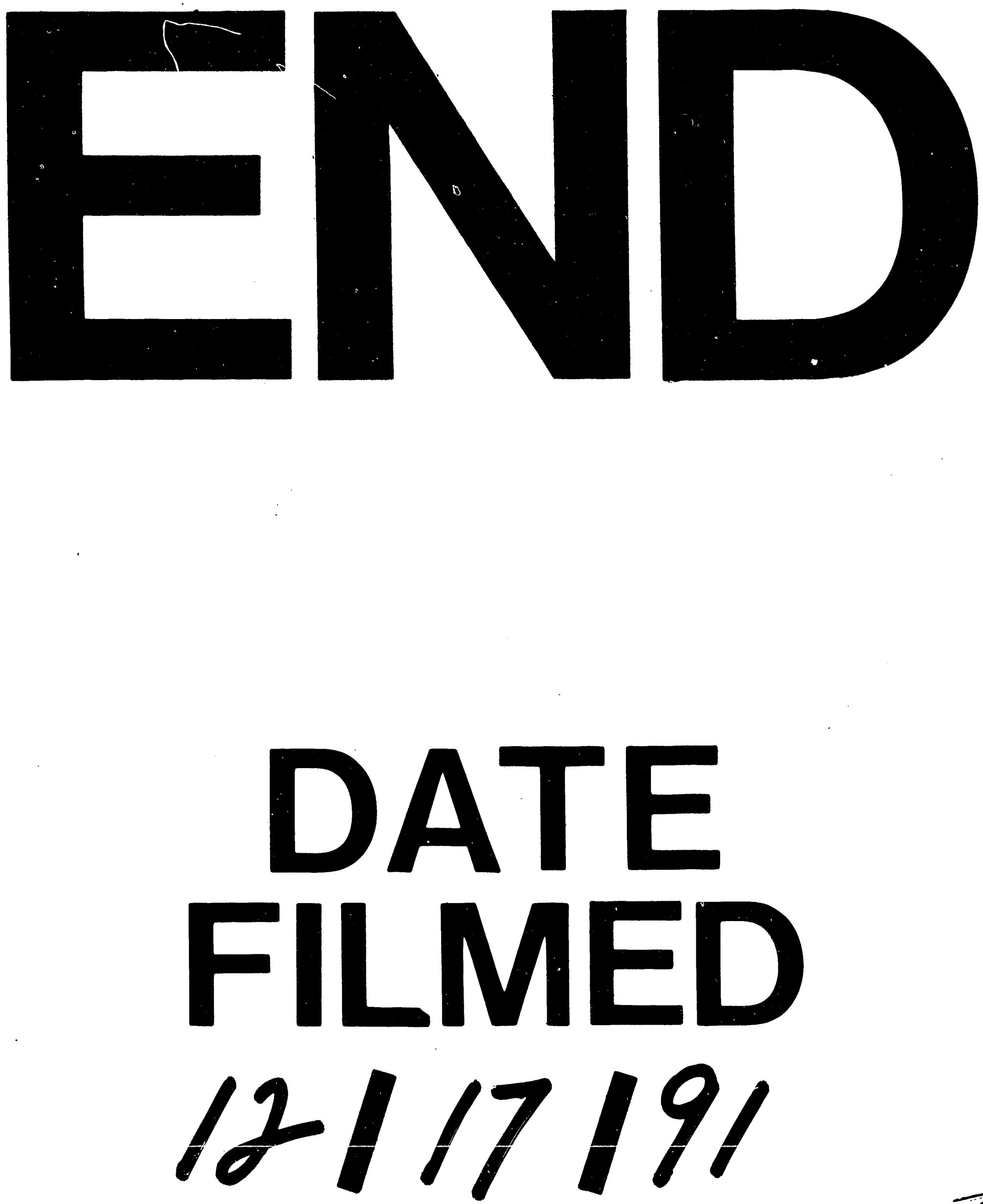
